\title{
Political Communication
}

\author{
Dannagal G. Young \\ Departments of Communication and Political Science \& International Relations \\ University of Delaware \\ Joanne M. Miller \\ Departments of Political Science \& International Relations and Psychological \& Brain Sciences \\ University of Delaware
}

August 18, 2021

Forthcoming, Oxford Handbook of Political Psychology (Third Edition)

Leonie Huddy, David Sears, Jack Levy, and Jennifer Jerit, Editors 


\title{
Political Communication
}

\begin{abstract}
This chapter argues that the conventional theories and processes at the core of the discipline of political communication are rooted in assumptions that no longer hold and contexts that no longer exist. Today's media users experience decentralized, interpersonal, horizontal, networked politically relevant communication every day. And they experience this sociallycontextualized messaging within a system predicated on the economics and logics of microsegmentation. We assert that these are qualitative shifts that necessitate a fundamental reconsideration and reimagining of the field of political communication. Specifically, we focus on how the shift away from traditional mass media models to networked, decentralized media systems through digital technologies has crucial implications for: a) the scope of what constitutes political communication and b) the integration of political psychology into the study of political communication.
\end{abstract}




\section{Political Communication}

All disciplines evolve and expand over time. With advances in analytical procedures and data availability, as well as paradigm shifts prompted by younger scholars and increased interdisciplinarity, such evolutions are to be expected. But when a discipline's theories and processes are rooted in assumptions that no longer hold and contexts that no longer exist - it is high time for a fundamental reconsideration and reimagination. It is in that spirit that we approach our discussion of the field of political communication.

In 2005, after having studied political communication for 40 years, Doris Graber, founding editor of the field's flagship journal, Political Communication, proposed a definition of political communication framed in terms of impact. Graber and Smith wrote, the field of political communication "encompasses the construction, sending, receiving, and processing of messages that potentially have a significant direct or indirect impact on politics. The message senders or message receivers may be politicians, journalists, members of interest groups, or private, unorganized citizens" (Graber \& Smith, 2005, p. 479). In this chapter, we embrace and expand upon Graber \& Smith’s (2005) already-broad definition and conceptualize political communication to encompass intentional, strategic, campaign-oriented discourse, but all forms of communications that "potentially have a significant direct or indirect impact on politics" (p. 479). Political communication is a discipline that is inextricably linked to context. As such, the logic, structure, and action-potential of media technologies (also known as "media affordances" see Faraj \& Azad, 2012) are central to any understanding of the ways in which the media shape and are shaped by public opinion and political behavior. We propose that the shift away from traditional mass media models to networked, decentralized media systems through digital technologies has crucial implications for: a) the scope of what constitutes political 
communication and b) the integration of political psychology into the study of political communication.

The organization of this chapter is as follows. First, we briefly review the accepted narrative of the field. Next, we discuss the ways in which the media landscape has changed, focusing on two broad and overlapping dynamics: 1) the decentralized, interpersonal, networked capacity of digital technologies, and 2) the economics of micro-segmentation. This is followed by a discussion of the implications of these dynamics for the study of the political psychology of communication processes - in terms of both what we study and how we study it - and thoughts about implications and future research.

\section{Established History of Political Communication}

As readers of comprehensive reviews of any research domain as vast as political communication are aware, authors must impose a structure on the literature, lest the text becomes a cacophony of theories, methods, findings, and implications. Although the specifics of these structures can be idiosyncratic, based on the author's and intended audience's intellectual emphasis and expertise, the broad contours of these organizational structures can become emblematic of a field. In political communication, the origin story is typically constructed in terms of three phases of media effects - hypodermic (media effects are powerful and direct), limited (media effects are rare and contingent), and subtle/moderated (whereas direct persuasion via the media may not be all that common, other types of media effects such as agenda-setting, priming, and framing can be consequential, especially under certain conditions and for certain types of people). For example, in their chapter for the $2^{\text {nd }}$ edition of this volume, Valentino and Nardis (2013) begin with a brief review of the three phases, then provide a comprehensive 
review of recent research, organizing their chapter in terms of four domains of influence: attention, learning, attitude change, and action. Other recent treatments are similarly structured and comprehensive (e.g. Iyengar, 2017; Jamieson, 2017; and Pooley, 2006). In this section, we briefly describe the history of the three phases (we point readers to the references cited above for more detailed treatments) to set the stage for our reimagining of the political psychology of political communication.

The birth of the formal study of media effects dates to the explosion of mass media offerings in the first half of the 20th century. First newspapers and magazines, then film and broadcast radio, followed by television, all garnered the interest - and concern - of sociologists and psychologists. Scholars feared that such far-reaching media with such vast audiences might have powerful "hypodermic" effects on the public's political attitudes and behaviors (Lasswell, $1927 ; 1930 ; 1935)$. "In the early days of communication study, the audience was considered relatively passive and defenseless, and communication could shoot something into them" (Schramm, 1971, p. 9). This perspective was rooted in post-war (both WWI and WWII) fears about propaganda, apocryphal (and exaggerated) accounts of the "mass hysteria" caused by $\mathrm{H}$. G. Wells' War of the Worlds radio broadcast (Cantril, Gaudet, \& Herzog, 1940), studies of the impact of WWII war bond drives (Merton, Fiske, \& Curtis, 1946), as well as the dominant social science theories of the day - mass society theory in sociology (Blumer, 1951; Durkheim, 1897; Kornhauser, 1959; Mills 1951; 1956) and stimulus-response theory in psychology (e.g. Guthrie, 1935; Hull, 1943; Thorndike, 1898; see Bineham, 1988 for a critical review of the received wisdom about this first phase of media effects).

However, early media effects studies were not bearing out the fears of a passive and defenseless audience. The People's Choice Study (Lazarsfeld, Berelson, \& Gaudet, 1948) and 
the American Soldier Studies (Merton \& Lazarsfeld, 1950) pointed to limited direct effects of media messages on attitudes and behaviors, instead pointing to processes like selective exposure, selective attention, and individual differences in media effects (Klapper, 1960; Lazarsfeld et al. 1948; Schramm \& Carter, 1959; Sears \& Freedman, 1967). People sought out media content that supported their preexisting views, avoided content that contradicted those views, and varied in their responses to media based on factors like education and religion, all of which suggested that media were far better at reinforcement than persuasion (Lazarsfeld \& Merton, 1948; Klapper, 1960). As Valentino and Nardis (2013,pg 2) summarize, “citizens, it seemed, didn’t pay much attention to politics, and when they did receive new information, it was primarily from friends and relatives they considered authorities on the subject (Katz \& Lazarsfeld, 1955)." This 'TwoStep Flow" notion of media influence-where political media content is filtered through "opinion leaders" in a social network and then relayed to less interested members of the grouphelped to explain why mass opinion change seemed so rare (see Druckman, Levandusky, and McClain, 2018 for a recent review and empirical confirmation of the two-step communication flow theory).

The cognitive revolution in media effects research in the 1980s-90s, with its focus on indirect effects of mediated messages on construct salience and judgment formation, meant that scholars could still assert that politically important media effects existed, even while acknowledging that strong, direct persuasion effects often did not. The agenda-setting effect of mass media (e.g. Iyengar and Kinder 1987; Miller 2007; McCoombs 2004; McCombs \& Shaw, 1972; McCombs and Shaw 1993) posited that mass media might not be influential in directly persuading audiences or telling them what to think, but were quite effective in telling the public what to think about. This increased the relevance of construct salience, mental models, and 
schema theory to the study of political communication and news effects. Soon the concepts of media priming (e.g. Iyengar \& Kinder 1987, Miller \& Krosnick 1996) and framing (e.g., Entman, 1993; Gross 2008; Iyengar, 1991; Nelson \& Oxley, 1999; Nelson, Oxley, \& Clawson, 1997; Scheufele, 1993; Scheufele \& Tewksbury, 2007), as well as the interconnections between agenda-setting, priming, and framing began to garner (and still receive) significant attention (e.g. McCombs \& Ghanem, 2001; McCombs, Llamas, Lopez-Escobar, \& Rey, 1997; RoskosEwoldsen, Roskos-Ewoldsen, \& Carpentier, 2002). The cognitive revolution also highlighted the logical pairing between the fields of political communication and political psychology. Such work framed media effects in terms of schema theory and mental models, and brought with it a renewed focus on individual differences in media effects. As audience "needs," "traits," and "evaluative dispositions" were found to moderate the impact of media on individuals, and the very mechanisms underlying the effects (e.g., Domke \& Wackman, 1998; Miller, 2007; Miller \& Krosnick, 2000; Oliver, 2002; Valentino and Nardis, 2013), human psychology became vital to the study of political media effects.

\section{Phases of Media Effects and the Changing Media Landscape}

This established history of the field of political communication, from hypodermic needle theory to limited effects to subtle/moderated effects (agenda setting, priming, framing, and their nuances) is characterized by shifts in theoretical perspectives resulting from changes in the media context and methodological advances. Such advances often necessitated revisions of previous conventional wisdom. The field of propaganda studies (e.g., Lasswell 1927), from which the hypodermic needle theory was born, was defined by the logic of broadcast media, through which centralized, powerful sources of information could deliver homogenous content to disconnected masses. With few opportunities to "talk back" to powerful message senders, few 
options for diverse content, few incentives for media outlets to produce diverse content, and no media infrastructure connecting members of the mass to one another, scholars feared that media audiences would be susceptible to large scale top-down propaganda campaigns.

With advances in survey and experimental methodologies and statistics, as well as new theories generated by the social-cognitive revolution in psychology (e.g. Barone, Maddox, \& Snyder, 1997), scholars found little empirical support for the hypodermic needle theory, concluding that the media had very limited effects (especially in the context of persuasion). Changes in the media landscape also played a role in the shift from phase one to phase two greater media options (in both form and content) in the mid- $20^{\text {th }}$ century gave individuals more choice. For the most part, individuals chose content that did not challenge their pre-existing beliefs, attitudes, and behaviors. As media continued to fragment and diversify in the late $20^{\text {th }}$ century, scholars pursued forms of media effects beyond direct persuasion, including subtle cognitive effects like agenda setting, priming, and framing reviewed above. The field also started to respond to the diversification of politically relevant content in early 2000s, integrating these cognitive theories into the study of political entertainment including talk shows, late-night comedy programming, and satire. (Moy, Xenos, \& Hess, 2006; Young, 2004; 2008). Expanding the study of media effects to sources not traditionally defined as "news" or "public affairs" has shown that just about any politically-adjacent content can provide information, set agendas, prime issues and traits, frame stories, and encourage political discussion and participation.

Starting with the earliest day of media effects research, scholars had defined "mass media communication" in terms of broadcast media such as newspapers, radio and television - media that "enabled one or a few individuals to reach an audience of many" and through which "feedback [from message receiver to message sender] was minimal" (Rogers, 1983). Such 
"linear and unidirectional" (Reardon \& Rogers, 1988) conceptualizations of communication such as Lasswell's (1948) "who said what to whom with what effect" made sense given the largely top-down, unidirectional nature of media technologies at the time. And throughout most of the $20^{\text {th }}$ century, mass media messages were produced and distributed by powerful message producers -who controlled the dissemination of messages to large, un-networked mass audiences. They were sustained either by the government, or (most notably in the U.S. context) by media corporations selling access to a large mass audience to advertisers. But advances in digital technologies and social media have transformed both the experience of media users and the economics of media industries. Today's media users experience decentralized, interpersonal, horizontal, networked politically relevant communication every day (Klinger \& Svensson, 2015). And they experience this socially-contextualized messaging within a system predicated on the economics and logics of micro-segmentation. Both of these changes make it necessary to position political psychology more centrally within the field of political communication.

In sum, shifts in the dominant theoretical approaches to the study of political communication throughout the $20^{\text {th }}$ century were predicated, in part, by the changing media landscape. We submit that despite numerous theoretical and conceptual advances, the "third phase" of the field of political communication research is predicated on the existence of a mass media system that - by and large - no longer exists (Chaffee \& Metzget, 2001). It is high time for a rethinking of the field of political communication. To be sure, we are not the first to argue that the qualitative differences between the media landscape of today and of yesterday necessitate such a rethinking. For example, Robison (2019) proposes an approach that centers on propaganda studies. And in their introduction to a special issue of Public Opinion Quarterly focusing on new approaches to political communication research in a changing media 
environment, Edgerly and Thorson (2020) highlight three themes that emerge from the articles in the special issue, prompted by a recognition of the fundamental changes to the media environment: 1) motivations to create and share political content (self-expression), 2) a renewed focus on digital inequities, and 3) methodological innovations. In this chapter, we focus on how the shift away from traditional mass media models to networked, decentralized media systems through digital technologies has crucial implications for: 1) the scope of what constitutes political communication and 2) the integration of political psychology into the study of political communication.

\section{Political Communication as Decentralized, Networked, and Interpersonal}

Digital technologies have become decentralized by design, rendering information redundant across the network and empowering individual users to create, share, and publicly react to information (Abbate, 2000). This "network media logic" (Klinger \& Svensson, 2015) means that individuals are both audience members and content producers; both recipients and participants (Ritzer \& Jurgenson, 2010). In the early 2000s, when platforms like Wikipedia, YouTube, Facebook, and Twitter reimagined the internet, they prioritized interactivity, user generated content, and horizontal interpersonal networks (O'Reilly, 2009). Web 2.0 took the decentralized control of the internet and placed it within overlapping socially-networked communities of friends, family members, colleagues, and neighbors. No longer was the audience a disconnected mass. No longer was the audience a mass (Chaffee \& Metzger, 2011). And as the lines between producer and receiver of information became increasingly blurred, no longer was the audience "an audience," but perhaps best described as "the people formerly known as the audience" (Rosen, 2008). 
By embedding political communication within a social context, digital technologies and social media require that we increasingly think of all political communication in terms of interpersonal communication (Holbert \& Geidner, 2009; Shah et al., 2017). Because of political communication's roots in rhetoric and top-down propaganda research, and because of the challenge of studying informal interpersonal communication, most historical considerations of political communication have not included examinations of discourse between and among regular people (McNair, 2011). And although political communication scholars have long studied interpersonal political discussion and deliberation (Eveland, Morey, \& Hutchens, 2011; Gastil, Black, \& Moscovitz, 2008; Stromer-Galley, 2003; Wojcieszak \& Mutz, 2009), these examinations have been considered separate from the study of strategic political communication, a distinction that is increasingly obsolete.

Recall that in the early days of media effects research, as strong persuasive effects of media messages were proving to be elusive, researchers did find indirect influence of media -in the form of communication between people, through social networks and trusted opinion leaders (Druckman, Levendusky, \& McClain, 2018; Lazarsfeld, Berelson, \& Gaudet, 1948). Today, with interpersonal communication embedded within digital media systems, constructs and processes relating to how people perceive, interact with, and respond to one another are increasingly relevant (Perloff, 2015). Cappella et al. (2015) describe, for example, the role of "impression and relationship-management" motives as increasingly important to the study of media effects in our socially-networked media environment (Cappella, Kim, \& Albarracin, 2015, p. 11). Characteristics and dispositional traits like conflict orientation (Sydnor, 2019), need for uniqueness (Lantian et al, 2017), empathy (Simas, Clifford, \& Kirkland, 2020) and statusseeking (Petersen, Osmundsen, \& Bor, 2020) all help bridge the gap between political 
psychology and the social context in which political communication is increasingly embedded. Walther (2017) recommends scholars make use of meta-constructs that bridge the mediainterpersonal divide, including social meta-constructs like relationships, interactivity, mutual influence, and social goals. Such approaches necessitate conceptual shifts from "factors to actors" (Cappella, 2017) and require scholars to recognize the interdependency of individuals within a social system and to consider how individual-level variables interact with explicitly social media contexts in studies of processes and effects.

\section{Political Communication as Fragmented and Micro-Targeted}

Accompanying these transformations that compel us to recenter interpersonal communication within the field of political communication, are changes in media logics (see Altheide \& Snow, 1979) and economics that encourage micro-targeting (Klinger \& Svensson, 2015). As the era of analog and broadcast gave way to cable and digital through the $1980 \mathrm{~s}-90 \mathrm{~s}$, media fragmentation - or the explosion in the number of media offerings - diffused audiences across hundreds of outlets, shrinking each individual audience and giving way to an era of media specialization and deliberate audience segmentation (Turow, 1997). Political communication scholars expressed concerns about the potential for media fragmentation to create "distinct issue publics" (Gurevitch, Coleman, \& Blumer, 2009, p. 170) and blur the lines of what constitutes professional journalism in ways that reduce public scrutiny and polarize the public (Mancini, 2013). The field produced empirical evidence of various forms of fragmentation-related polarization; ideological polarization stemming from exposure to like-minded content (Baum \& Groeling, 2008; Stroud, 2011) and political interest polarization, whereby individuals who preferred entertainment over information could drop out of the political media ecosystem altogether (Prior, 2007). 
Specialized cable channels and the Internet of the early 2000s were indeed fragmented, but the era of Web 2.0 born after 2004 (O'Reilly, 2009) transformed specialized media to "micro-targeted" media - communications that utilize user data to develop highly tailored media experiences driven by user socio-demographics, psychological characteristics, geographic data, and online consumer and social behaviors. Such "connectivity data" (Van Dijck, 2013) inform algorithms designed to maximize site visits and time on site in a hyper-competitive media environment. The economics of media competition have always encouraged the creation of public affairs content that is decontextualized, personalized, emotional, conflict-driven and dramatic (Bennett, 2016; Spencer \& Spencer, 2007). Such norms lead to news content that contributes to various cognitive effects; from horse-race and strategy coverage that fuels political cynicism (Bennett, 2016; Cappella \& Jamieson, 1997; Patterson, 1993) to episodically-framed personalized news (see Iyengar, 1991) that increases the audience's perceptions that individuals (rather than institutions or government) are responsible for their own political, social or economic fate (Gross, 2008). Scholars warn that the increasing consolidation of news industries and reduced quality of journalism, coupled with media fragmentation and polarization, will have detrimental effects on democracies around the globe (Van Aelst et al., 2017). Moreover, these dynamics are playing out in the midst of a vast sea of user data; data which increasingly inform the behaviors of media producers - regarding media content, argumentation, tone, aesthetics, and distribution (Deibert, 2019; Jamieson, 2013).

Whereas psychology used to enter the media effects conversation in the form of cognitive processing mechanisms and "individual difference variables" (see Oliver, 2002), today psychological processes and traits are anticipated by content producers and distributors. Audience psychology is "baked into" media products and media strategies from the start, to 
attract, arouse, and solidify connections with individual users and viewers. This is perhaps most obvious in the context of psychologically micro-targeted political advertising through social media platforms (Krotzek, 2019; Kruikmeier, Sezgin, \& Boerman, 2016; Zarouali, Dobber, DePaw, and de Vreese, 2020). But the splintering of the information ecosystem has also increased the ability (and need) of message producers across media forms to create emotionally evocative, psychologically compatible (to their intended audience) content - in terms of both substance and aesthetics. Psychological traits such as tolerance for ambiguity which correlate with political ideology (Jost et al., 2003) and aesthetic preferences (Cleridou \& Furnham, 2014) may account for the distinct look and feel of genres preferred by liberals and conservatives (Young, 2019). In other words, media content is being strategically created to attract specific audiences, based on their psychological make-up, preferences, and identities. Such "microsegmentation" is dominating political media decisions and contributing to the production of content that will persuade connected individuals to watch, to use, to read, to engage, and to return. We assert that these drastic changes to the media landscape require even greater integration of political psychology into the study of political communication - especially the psychology of aesthetics (Jacobsen, 2006; Pels, 2003), political ideology (Jost et al., 2003), social/political identity (Huddy, 2001; Huddy, Mason, \& Aarøe, 2015), and emotion (Albertson \& Gadarian, 2015; Webster, 2020; Young, 2019) in ways that eschew any vestiges of the notion that political communication consists of a distinct non-strategic content creator, on the one hand, and a passive content receiver, on the other.

Both transformations stemming from the digital media ecosystem - the decentralized, networked, interpersonal logic on the one hand and the fragmented, micro-segmented logics and economics on the other - are interrelated and mutually reinforcing. In the following pages, we 
reflect on the implications of these transformations for various political communication theories and processes and discuss their significance for the role of political psychology within political communication. Harkening back to Lasswell's (1948) model of media communication, we first discuss the ways in which these media transformations have fundamentally revolutionized the production of political communication (the "who"). We then review research that reconceptualizes the audience as active participants in the political communication process (the "whom"). Next, we discuss some of the ways in which the decentralized/networked/interpersonal and micro-segmented media landscape affects media content (the "what"), focusing specifically on emotional content and the production and spread of misinformation. Finally, we discuss how these processes affect message processing, our shared (or not) "reality," and political polarization (the "with what effect" of Lasswell's framework).

Our choice to organize this reimaging of the field of political communication in terms of the who, the whom, the what, and the effects is not without its drawbacks. In making this choice, we are conscious of the fact that we are adopting a framework borne out of a media context that no longer exists. After much deliberation, it seemed to us that Lasswell's (1948) framework actually spotlights, rather than obscures, the stark differences between the media landscape of yesterday and the media landscape of today.

\section{The "Who"}

We begin with the who. The conventional conceptualization of the sources of political communication focuses on elites - primarily news executives, professional journalists, politicians, and pundits - as the sole broadcasters of information, and of professional media 
organizations as the conduits of that information. In this section, we explore recent theoretical and empirical work that helps us reconceptualize and broaden our understanding of the "who."

From Gatekeepers to Curated Information Flows. With the advent of decentralized control over the flow of information and the shift from a vertical and disconnected to a horizontal and networked experience of media users, the role of information "gatekeepers" has fundamentally changed (Shoemaker et al., 2001). Whereas news executives and organizations used to have the unique power to "winnow, shape, and prod potential news messages...into those few that are actually transmitted by the news media" (Shoemaker et al., 2001, p. 233), that gatekeeping power has now been diffused across individuals, politicians, political organizations, social media platforms, and even rogue political actors.

Individual citizens, in the role of information producers and sharers, play the role of “citizen journalists" (Wall, 2015) or "participatory journalists” (Fröhlich, Quiring, \& Engesser, 2012), motivated by dissatisfaction with traditional news, a desire to engage/challenge dominant narratives, and to connect with others to acquire ideas and experiences (Fröhlich, Quiring, \& Engesser, 2012; Kim \& Lowrey, 2015). On the recipient side, citizen journalism is viewed as most credible by those who are already cynical and skeptical about media in general (Carr et al, 2014). Videos of hostile encounters between citizens and government officials such as the military or police have complicated dominant elite narratives (Ali \& Fahmy, 2013; Meraz, 2009), negatively affected viewers' perceptions of law enforcement (Boivin et al, 2017; Parry et al, 2019), and contributed to the growth in social justice movements (Anthony \& Thomas, 2010; Jacobs, 2010). Recognizing the value - and appeal - of citizen journalism, some news organizations have integrated more user generated content (Thurman, 2008) and non-elite sources into their reporting (Hermida, Lewis, \& Zamith, 2014). Such shifts in the definitions of 
"journalism" and "objectivity" are illustrated in scholars' calls for professional journalists to reject objectivity, tap into their authentic moral voices, and draw upon their experiences, communities, and identities as they engage with events and issues (Carlson, Robinson, \& Lewis, 2021). While these changes are operating at the level of media production, they can affect how individuals select and process political information. Kelly (2019), for example, illustrates how perceptions of objectivity and credibility of news stories from unknown sources are driven by pre-existing beliefs, leading to higher perceptions of bias when encountering balanced news than belief-confirming news.

The declining formal role of elite journalistic gatekeepers also means more opportunities for direct strategic communication from political elites to citizens, although empirical examinations reveal these instances of "direct-to-voter" social media communications are rare (Kleis Nielsen \& Vaccari, 2013). In The Rhetorical Presidency, Tulis (1987) introduced the concept of "going public" to refer to presidents bypassing interactions with Congress by directly addressing the American people on matters of policy. Scacco and Coe (2021) expand on this with the concept of the "Ubiquitous Presidency" whereby digital technologies allow certain elites (namely, President Trump) to communicate directly with followers and avoid journalistic inquiry and accountability, while still relying on message amplification and legitimacy from news outlets. Direct communications from public officials to supporters increases opportunities for "para-social" interactions, through which individuals feel that they have intimate relationships with people they do not actually know in real life (Horton \& Wohl, 1956). These perceptions can shape both cognitive and affective aspects of message processing (Lee \& Shin, 2012), including increasing affinity for like-minded politicians through the para-social bond created through exposure to their Twitter feeds (Paravati et al, 2020). 
Meanwhile, news organizations have become increasingly dependent on search engines and social media for the distribution and reach of their content (Kleis Nielsen \& Ganter; 2018), leading some to call these "digital intermediaries" our new gatekeepers (Kleis Nielsen, 2016; Powers, 2017). Yet, digital intermediaries are not acting alone in curating the flow of information. User behavior and preferences inform the criteria that intermediaries use to shape information curation and distribution (Pariser, 2011). Wallace (2018) urges that we think about digital gatekeeping in terms of individual actors, algorithms, and platform incentives; or: "who is selecting which information according to what selection mechanism, and how is the news item framed before reaching the public?" (p. 288). Thorson and Wells (2016) conceptualize these processes not as gatekeeping, but as "curated information flows" through which journalists, strategic communicators, individual media users (personal curators), social contacts, and algorithmic filters all shape an individual's mediated experience.

\section{Entertainment TV and Beyond as Conduits for Political Communication. Not only does} today's qualitatively different media environment require scholars to redefine the "who" as being everyone, it also requires us to think more broadly about the channels of that communication. Media fragmentation and accompanying changes in the economics of media fueled an evolution in political media forms and genres through the 90 s to today. The distinction between news and entertainment that had been embedded into network television broke down as cable and the internet allowed - and encouraged - the creation of new hybrid genres of information (Baym, 2017; Chadwick, 2017; Williams and Delli Carpini, 2011; Young \& Gray, 2013). Political communication scholars began studying the political content and effects of late-night talk shows (Niven, Lichter, and Amundson, 2003; Young, 2004), daytime talk shows (Baum \& Jamison, 2006; Glynn et al., 2007), historical reenactment films (LaMarre \& Landreville, 2009), and 
narrative documentaries (Whiteman, 2004). Rather than remaining handcuffed by the false distinction between "political communication" and "entertainment," theory-driven analyses have revealed important political consequences of exposure to programming designed to entertain.

In the context of late-night comedy research alone, researchers have found evidence of political and public policy knowledge acquisition (Becker \& Bode, 2018; Cao, 2008; Hardy et al, 2014), increased political discussion and participation among viewers (Feldman and Young, 2008; Landreville, Holbert, \& Lamarre, 2010), increased attention to and awareness of politics and public policy (Brewer et al, 2018; Feldman, Leiserwitz, and Maibach, 2011) and increased information seeking from - and attention to - more traditional political content (Feldman and Young, 2008; Xenos and Becker, 2009). Importantly, many of these effects of exposure are conditional upon the individual characteristics of the audience - including political knowledge (Young, 2004), political interest (Xenos and Becker, 2009), age (Cao, 2008), and ideology (Lamarre, Landreville, and Beam, 2009).

Research has also begun to illuminate the ways in campaign communications are affected by digital and social media affordances, described by Perloff (2015) as "the quintessential media features that facilitate actions or trigger psychological heuristics" (p. 549). According to Faraj and Azad (2012), media technologies shape the potential for users to engage in certain actions by virtue of their structures and internal logics. These "action-potentials" - or social media affordances - are especially implicated in political campaign communications (Bossetta, 2018), as evidenced by the fact that digital technology companies promote their platforms to candidates and work with campaigns to help them take advantage of platform characteristics to target likely voters (Kreiss and McGregor, 2018; see also Towner and Baumgartner (eds; 2021) for new 
research on how candidates and campaigns leveraged new media technology to reach potential voters during the 2020 elections).

Whereas political communication textbooks through the mid-1990s typically limited the concept of political communication to news, political advertising, and political debates, contemporary scholars explore the content, psychology, and effects of any mediated form of information that might have political implications. Recent work points to the relationship between videogame play and less support for democratic and prosocial values (Bacovsky, 2021), increased postfeminist attitudes among viewers of YouTube makeup tutorials (Chae, 2019), the civic role of online meme culture (Penney, 2019), and the playful exploration of contentious issues related to gender and power on the social media platform, TikTok (Vijay \& Gekker, 2021). Social scientists have also begun to explore complex phenomena such as "Black Twitter" as a place where People of Color construct (Harlow \& Benbrook, 2019) and perform (Florini, 2014) racial identity and advance counternarratives (Graham \& Smith, 2016). Political scientists have also studied the intersection of sports, media, and politics, including how perceptions of NFL's Colin Kaepernick's public protests of police brutality are shaped by political and racial attitudes (Stepp \& Castle, 2021; Towler, Crawford, and Bennett, 2020).

\section{The "Whom"}

The reimagining of the "who" discussed above blurs the lines between who and whom to such a degree that we risk creating a distinction without a difference. Not only are the traditional receivers of political communication now also producers of that content, but the new media landscape provides them with more opportunities to be active and effective seekers of information, while also incentivizing the strategic curation and packaging of content by 
producers (at both the elite and mass level) seeking to attract their intended audience. The notion of agency - who has it and what it even means - has been upended.

Uses and Gratifications. Uses and Gratifications (U\&G) approaches to the study of media, popularized in the 1970s (Katz, Blumler, \& Gurevitch, 1974; Rubin, 1984; Rubin \& Rubin, 1982), offer a valuable framework to consider both why people engage with media and how they process and are shaped by media experiences as a result. When originally developed, U\&G's assumption of an active audience that "used media" to meet certain needs and gratifications contrasted sharply with that of the old passive-audience-centered media effects paradigm. When integrated with effects mechanisms, researchers found the impact of media exposure on outcomes like learning and message engagement was contingent on the needs and gratifications that guided media behaviors in the first place (Rubin, 1983).

In the digital media environment, the networked, interactive, and customizable "media affordances" (Sundar, 2008, Sundar \& Limperos, 2013) ought to shape not only media effects mechanisms, but the very needs and gratifications users seek to satisfy through media use (see Perloff, 2015). Perloff (2015), for example, suggests that future U\&G approaches integrate the affordances of digital technologies with unique psychological characteristics of the user to posit novel sets of uses and gratifications that individuals might seek to satisfy through media use. For instance, he points to Bergman et al's (2011) finding that although narcissism does not predict time spent using social media among Millennials, it does predict the reasons why they use social media - to increase their number of friends, share their activities, and project a positive image. Since motivations for media use shape affective and cognitive processes associated with that usage, motivational distinctions ought to be factored into political media effects mechanisms. Perloff also urges the integration of neuroscientific approaches to better understand 
neuropsychological processes that correlate with individuals' media orientations and anticipated rewards. Consistent with the efficacy of such approaches, Sherry (2001) found significant correlations between television viewing motivations and various traits that share neural substrates, namely: mood, task orientation and cognitive rigidity.

Early integrations of U\&G approaches helped explicate how media user orientations and motivations shape cognition, attitude, and behavior effects (McLeod \& McDonald, 1985). More recent applications have explored how motivations to use mobile messaging apps affects political discussion and efficacy (Pang, 2018), how audience motivations rooted in social utility shape political participation through social media use (Chen \& Chan, 2017), how surveillance and escapism gratifications predict news consumption among college students (Diddi \& LaRose, 2006), and how social media platform adoption is associated with motivations including hedonism, self-esteem, belonging, and reciprocity (Pai \& Arnott, 2013). Illustrating the integration of interpersonal communication theory with $U \& G$ approaches in the context of political communication, Pennington and Winfrey (2021) find that individuals who are more social and interpersonally-focused in their online behaviors are less likely to discuss politics on Facebook.

The Importance of Social Identity. There is increasing recognition in the field of political communication that the fragmented and interpersonally networked information landscape makes identity-driven motivations increasingly relevant to the processes outlined above (see, for example, Slater, 2007). Tajfel \& Turner's Social Identity Theory (SIT; see Tajfel \& Turner, 1979;) and Turner and Oakes' concept of self-categorization (1986) offer useful frameworks for considering the ways in which identity shapes media preferences and effects. Even before the birth of social media, Blumer \& Kavanagh (1999) discussed the intersection of media 
fragmentation and identity, noting the "increased social differentiation and specialization, [and the] fragmenting [of] social organization, interests, and identities" through media. In his 1998 Ithiel De Sola Pool lecture, Bennett (1998) highlighted declining confidence in institutions and the rise in "lifestyle politics" resulting from economically-driven social fragmentation. He also characterized the splintering of the media system as both a response - and contributor - to these trends. In 2008, Bennett and Iyengar revisited the concept of identity, arguing that among young people in particular, we see "shifting and far more flexible identity formations that require considerable self-reflexivity and identity management." (p. 716), including through their media behaviors.

But while political communication scholars were recognizing the increasing salience of identity-based motivations in political life, political psychologists were pointing to the limits of SIT in political contexts (Huddy, 2001). Yet, even while urging caution, Huddy (2001) acknowledged the capacity of "category salience" to shape identity in a given context with potentially important consequences. We propose that interpersonally networked and microsegmented digital political media are tailor made (quite literally) to be just this: a context designed to activate and prime the salience of our identity categories. The microtargeting of symbols and texts through digital media, combined with the incentives to "perform identity" in an interpersonally networked social media context (Vaidhyanathan, 2018), speak not only to group "boundaries" but also to group "meaning" consistent with self-categorization and social identity theories (Haslam, Turner, Oakes, McGarty, \& Hayes, 1992). Recent work points to the intersection of user psychology and social media logics in incentivizing fast, inattentive - and often identity-based - motivations, over accuracy-based motivations (see Fazio, 2020; Pennycook et al., 2021). 
In the U.S. context, socio-demographic, political and psychological characteristics are increasingly enmeshed and overlapping (Mason, 2018). This partisan separation along racial, religious, and geographic lines, is accompanied by an epistemic separation on the left and the right (Oliver and Wood, 2018). This "social" and "epistemic" sorting, combined with the economics and logics of fragmented and digital media, means that identity categories are used, reinforced, and cultivated through the process of political communication itself, with implications for political polarization and affective polarization (see Iyengar, Sood, and Lelkes, 2012). These dynamics are the essence of Slater's $(2007$; 2015) Reinforcing Media Spirals (RMS), which proposes that identity motivates media behaviors in ways that reinforce that identity. Importantly, according to RMS, when one's identity is perceived to be under threat, these patterns are exacerbated, such that media use not only reinforces identities, but can facilitate their polarization (see Long, Eveland, \& Slater, 2018).

\section{The Psychology of Media Selectivity: Beyond Political Attitudes. Whereas media} fragmentation facilitates selective exposure and avoidance behaviors based on political ideology and political attitudes, it also invites people to make media selections based on content preferences and psychological traits. Sydnor (2019), for instance, illustrates that individuals who are conflict averse intentionally avoid uncivil political media, hence contributing to gaps in political engagement based on gender and race. Gerber et al (2011) find that individuals high in openness, extraversion, and emotional stability are most likely to consume political media and that these traits shape preferences for specific genres of political information as well. People who prefer entertainment over information can selectively avoid political content altogether, leading to a decline in political knowledge and voter turnout among those least politically inclined (Prior, 2007; Toff \& Kalogeropoulos, 2020). But just as social media might allow incidental exposure to 
ideologically-diverse political information through friends and family, so too might social networks diversify media experiences in general, encouraging, for example, news consumption among younger and less politically interested users (Fletcher \& Nielsen, 2018)

Integrating the study of aesthetic preferences - style or taste - into political communication research presents a rich opportunity for political psychologists studying media selectivity patterns and effects. Pels (2003) explains that "political style or taste refers to the fact that judgments of persons ... normally have a holistic and unarticulated character..." and proposes that bringing aesthetics and "style" into the study of politics "usefully bridges the divide between form and content, detail and essence, presentation and principle, sentiment and reason, and hence relativises a one-sided cerebral or rationalist approach to political behavior" (p. 48). Integrating the concepts of media "style," "packaging" or "aesthetics" allows us to move beyond classic message features (like political topics, argument quality, message source or medium), to consideration of look, feel, tone and style of political symbols and texts. Understanding how such characteristics resonate with user psychology may help explicate selective exposure, selective processing, and even selective production (see Cui et al, 2020). This is especially true in a socially- and epistemically-sorted and yet networked political media ecosystem in which media organizations are economically incentivized to tailor their content to the presumed psychological characteristics, identities, and aesthetic preferences of their intended audience.

One example of the integration of aesthetics into political psychological approaches to communication is found in the study of political entertainment. As reviewed above, the boundaries between entertainment and news have eroded (Williams and Delli Carpini, 2011; Young \& Gray, 2013), resulting in media content and genres that are increasingly hybrid; unruly 
combinations of forms, categories and structures (Baym, 2017; Chadwick, 2017 ). These combinations part entertainment and part news - part serious and part play - create fertile ground for political psychologists studying political communication, as individuals' tolerance for ambiguity likely affects their comfort with such blendings (Young, 2019). Work on the psychology of aesthetic preferences indicates that tolerance for ambiguity and need for cognition are correlated with preferences for artistic (Wiersema, Van Der Schalk, \& van Kleef, 2012) and musical styles (Rawlings et al, 2000). Young (2019) thus proposes that ambiguous ironic satire is compatible with the psychological correlates of social and cultural liberals - high in tolerance for ambiguity and need for cognition (see Jost et al, 2003), hence accounting for the left-leaning "bias" of much political satire; as well as the right leaning "bias" in didactic, literal, morally serious “outrage programming” (see Berry and Sobieraj, 2014). Such considerations are important as scholars study how individuals engage with politically-relevant hybrid media forms including historical reenactment films (LaMarre \& Landreville, 2009), political talk shows (Roth et al, 2014) and even journalists' twitter profile pages (Ottovordemgentschenfelde, 2017).

Another fruitful application of the concept of "political media as aesthetic" comes from recent work on the psychology and appeal of populism. Its thin ideology, appeal to "traditional popular values," and antagonistic divide between "the people" and "elites" (see Mudde, 2004; Stanley, 2008) have led political communication scholars to describe populism itself as a "communication style" rather than a political ideology (Bracciale, \& Martella, 2017; De Vreese et al, 2018; Jagers \& Walgrave, 2007). Populism as an aesthetic is thus emotionally evocative, intimate anti-establishment messaging focused on regular people, that draws a contrast between the monolith of good people and corrupt elites (Bracciale \& Martella, 2017). Such aesthetics are likely to interact with audience psychology in ways that appeal to and mobilize certain kinds of 
individuals more than others, such as those who score lower in agreeableness (Bakker, Schumacher, \& Rooduijn, 2021) higher in need for closure and certainty (Kruglanski, Molinario \& Sensales, 2021), and narcissism and psychopathy (Nai \& Martinez i Coma, 2019).

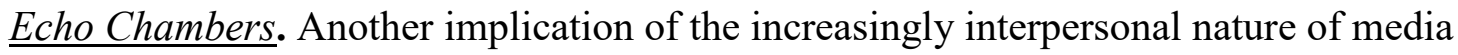
experiences and the micro-segmentation of audiences is the potential formation of echo chambers and filter bubbles. As media choice increases, individuals can increasingly "opt in" or "out" of media experiences, facilitating selective exposure to and avoidance of ideologicallyconsonant - or even politically-relevant (Prior, 2007) - media content. In their paradigmchallenging essay, Bennett and Iyengar (2008) suggested that selectivity behaviors would be so great in this new media landscape, that media persuasion effects would all but disappear, even as other effects like agenda setting or priming might continue. "As media audiences devolve into smaller, like-minded subsets of the electorate," they wrote, "it becomes less likely that media messages will do anything other than reinforce prior predispositions. Most media users will rarely find themselves in the path of attitude-discrepant information.” (p. 724)

Such "echo chambers" or "filter bubbles" became a growing concern among political scientists and political communication scholars from 2000 - 2010s (Sunstein, 2001), as empirical examinations pointed to a public engaging in selective exposure and avoidance of politicallydissonant mediated information in ways that could fuel political polarization (Stroud, 2011; see below). Yet, while echo chambers and filter bubbles are certainly made possible through media fragmentation, research has failed to produce substantial evidence to support the notion that most people restrict themselves to only like-minded media content (see Guess et al, 2018; Guess, 2021). Although selective exposure to like-minded content does occur, and moral-emotional content from elites spreads efficiently within their ideological social networks (especially on the 
right) (Brady et al., 2019), evidence of selective-avoidance of belief-disconfirming information is scarce (Garrett, 2009). Barbera et al, (2015) conclude that "homophilic tendencies in online interaction do not imply that information about current events is necessarily constrained by the walls of an echo chamber" (p. 1539).

Users tend to have diverse media diets and vary in the extent to which they pay attention to political or current events information (Guess, 2018), and those users who do pay attention to like-minded political content, pay more, not less attention to belief-dissonant programming (Garrett, Carnahan, \& Lynch, 2011, Nelson \& Webster, 2017). Even on social media, where algorithms and users themselves increase the ideological homogeneity of their newsfeeds (Bakshy, Messing, and Adamic 2015), users are still exposed to some belief-disconfirming information. In fact, in the most fragmented context of all, the internet, selective exposure and avoidance is complicated by social networks, where social media posts of friends and family can serve as heuristics that guide ideologically diverse information consumption (Masip, SuauMartinez, \& Ruiz-Caballero, 2017; Messing and Westwood, 2014; Flaxman, Goel, \& Rao, 2016; Zuiderveen et al., 2016), even trumping partisan selective exposure (Anspach, 2017). These results are supported by Dylko et al (2018) who find that although customized media experiences increase selective exposure dynamics in ways that increase political polarization, this effect is limited to customization processes that are automatically embedded within a technology. When users have the ability to customize media experiences, these relationships shrink, again highlighting how user agency often diversifies - rather than homogenizes - media diets. Such findings certainly call into question Bennett and Iyengar's (2008) pronouncement of the "demise of the inadvertent audience" (p. 717). Whereas media fragmentation facilitates selective 
exposure and avoidance, the interpersonal networked nature of the social media experience does not.

Yet attending to and being receptive to belief-disconfirming content are two different things that may be motivated by different goals. Knobloch-Westerwick and Klienman (2012), for example, find that people engage in less selective avoidance of belief-disconfirming information when they expect their side is going to lose, pointing to anticipated "informational utility" as individuals anticipate that exposure to belief-disconfirming content "can aid individuals in making future decisions" (p. 171). Valentino et al.'s (2009) work is consistent with this explanatory mechanism, with individuals seeking out belief-disconfirming content as a way of monitoring their information environments. In this work, anxiety was found to fuel information seeking behaviors, thereby increasing exposure to belief-disconfirming content, illustrating that these consumption behaviors are shaped by emotional needs of the audience.

Finally, calls to relax the fears of echo chambers and filter bubbles are focused on the modal cases - the most likely outcomes for most people. This raises questions about whether we should be more concerned about the outcomes of users at the margins - culturally and politically. Boutyline and Willer (2017) for example, found that social networks (on Twitter) were most homogenous among those users with the most extreme political views. Evidence about the moderating role of political engagement is mixed; Guess (20121 finds a positive relationship between political engagement and media diet homogeneity, whereas Dubois and Blank (2018) find the reverse (see also Eady et al. 2019). Emotions such as anger may fuel the kind of dynamics that lead to concerning echo-chambers, while fear and anxiety may mitigate them (Wollebaek et al., 2019). Recent work by Stier et al. (2020) indicates that populist attitudes interact with contextual factors to fuel selective exposure patterns, with populist attitudes 
contributing to lower (but not zero) exposure to traditional news and greater exposure to hyperpartisan outlets.

The intersection of misinformation and echo-chambers has given rise to renewed interest in how misinformation may thrive and spread through online networks (Törnberg, 2018). This has led some to consider how mere exposure to belief-discordant information within a vocal and ideologically homogenous social networks might still facilitate anti-democratic and polarizing outcomes. In Garrett's (2017) condemnation of "the echo chamber distraction," he highlights the potential dangers of "engagement echo chambers" or networks that have the capacity to promote falsehoods merely by "consistently affirming one view" (p. 371).

\section{The "What"}

Both the networked/interpersonal nature of the media landscape today, as well as the expansion of media outlets and corresponding economic incentives to create micro-targeted content that will garner the largest audience possible, have had profound effects on the content of political communication - the "what." A comprehensive review of the myriad ways in which the new media landscape has reshaped content production is beyond the scope of this chapter. Here, we briefly review scholarship that highlights two such transformations - hyper-emotional content and the spread of falsehoods and conspiracy theories.

Emotional Content. Since the early 2000s there has been a growing recognition of the importance of emotions in political communication (e.g. Marcus, Neuman, \& MacKuen, 2000; Neuman et al. 2007). For many years, this research was primarily focused on the effects of political ads - most notably, the impact of negative ads on candidate ads and voter turnout (Brader, 2006; Chang, 2001; Geer, 2006; Kahn \& Kenney, 1999; Mattes \& Redlawsk, 2014; Tedesco, 2002, Valentino et al., 2011). The questions guiding this fruitful line of research center 
around the role of emotions in the political persuasion process (e.g. Albertson and Gadarian, 2015). The decentralized, fragmented, and networked nature of today's media environment has opened the door for a new set of questions about the ways in which media organizations and algorithms strategically push emotional content aimed at attracting clicks, likes, and shares, as well as the effects of such content. These new lines of research have documented differences in the positive vs. negative emotionality of news content in traditional media outlets and on social media (e.g., Soroka et al. 2018), as well as whether information that is positive or negative in tone is more likely to be shared. Evidence on this second point is mixed, with some scholars finding that negative information is more likely to be shared than positive information (Godes et al. 2005; Hasell \& Weeks 2016), and others finding that positive information is more likely to be shared (Berger \& Milkman 2012; Kraft et al. 2020). Aaroe and Peterson's (2020) work suggests that episodically framed news stories that resonate with our pre-existing cognitive biases are more likely to be shared and to shape our attitudes when they are experienced and processed through interpersonal networks. Meanwhile, Brady et al. (2017) find that content that includes moral-emotional language is more likely to be shared than less emotional content.

In her book, Disrespectful Democracy: The Psychology of Political Incivility, Sydnor (2019) demonstrates the central role that the psychological construct of conflict orientation plays in our understanding of the effects of emotionally arousing media content. Through experimental and survey research, she demonstrates how people who are more "conflict avoidant" are more likely to experience negative emotions (anxiety, disgust, and anger) in response to televised incivility, whereas those who are "conflict approaching" are more likely to experience positive emotions (like being entertained and amused) in response to that same content. Those who are conflict averse are then turned off by political media and more likely to opt out of political 
content altogether. Building on the work of Mutz and Reeves (2005) which explored how televised incivility can increase attention while disrupting other forms of cognitive processing, Kosmides and Theocaris (2020) find that social media incivility can actually induce positive emotions (enthusiasm), especially amongst those for whom the content is attitude-consistent. Borah (2013) points to the anonymity afforded by social media as one of the drivers of incivility, and finds that uncivil news frames are a double-edge sword, increasing the credibility of a news article, on the one hand, while also decreasing political trust and efficacy.

Misinformation and Conspiracy Theories. In 1944, former head of "Rumor Control" for the Massachusetts Committee of Public Safety Robert Knapp defined "rumor" in Public Opinion Quarterly as, "a proposition for belief of topical reference disseminated without official verification" (p. 22). He described rumors as providing detailed "information" spread by word of mouth that satisfy some emotional or psychological need of a community. It is the "spread by word of mouth" element that imbues the decades-old concept of "rumors" with increasing relevance in today's social media ecosystem. In their prescient 2000 article, Kuklinski et al. argue that the conventional "informed vs. uninformed" dichotomy conflates two very different uninformed people - those who do not know the facts, on the one hand, and those who believe false information (the "misinformed"), on the other. They called for more research on the causes and consequences of misinformation ("information that is false, but the person who is disseminating it believes that it is true" (Wardle \& Derakhshan, 2018, p. 44)), pointing to the potential deleterious effects of a misinformed public that is likely to resist facts that contradict their misinformed beliefs. Vraga \& Bode (2020) call for a differentiation between information that is false and information that is merely unsubstantiated, such as operationalizing misinformation as "information considered incorrect based on the best available evidence from 
relevant experts at the time" (p. 138) for example. Such distinctions would take into account the fluid nature of expert consensus, especially from such domains as science and law.

Disinformation, in contrast, is "information that is false, and the person who is disseminating it knows it is false" (Wardle \& Derakhshan, 2018). Efforts to spread information that is knowingly false violates the free will and transparency assumptions at the heart of persuasion theory (see Perloff, 2020). Disinformation is thus more akin to propaganda and deception. Propaganda and persuasion scholars have long recognized that mass media propaganda, absent supplementary interpersonal messaging, was unlikely to persuade audiences (Lazarsfeld \& Merton, 1948). Because decentralized social media embed media messaging and user generated content within interpersonal networks, disinformation and other forms of propaganda that are spread through these channels may be at a persuasive advantage (Young \& McGregor, 2020). Jamieson (2020) chronicles how Russian propaganda operatives - especially online "trolls" - capitalized on the decentralized and networked logics of Facebook to exploit preexisting cultural cleavages during the 2016 U.S. Presidential Election. She also illustrates how news organizations, driven by biases towards personalized, conflict-oriented news, legitimized and amplified these disinformation efforts. Munger (2019) argues that economic incentives that drive clickbait media lead to "credibility cascades" that enable misinformation to flourish. Meanwhile Garrett (2017) argues that the threat posed by deliberate politically-strategic disinformation campaigns is far greater than the threat posed by the logics of the technologies themselves. He also explores how citizens might use the affordances of social media platforms to increase information accuracy, accountability, and civility.

Yet research on how elite-driven disinformation interacts with media affordances, logics, and economics paints a far clearer picture of democratic harm than of democratic health. 
Rhetoric scholars have detailed how political elites such as Donald Trump (Mercieca 2020) make strategic use of the affordances of the new media landscape to spread falsehoods directly to the public. Using the metaphor of a polluted landscape, Philips and Milner (2021) explore how polluted information such as white supremacist ideology and conspiracy theories have permeated the media landscape, and point to the interconnected, intertwined, and deeply networked nature of mis- and disinformation as being particularly pernicious and difficult to combat, and Rosenblum and Muirhead (2020) identify a new form of conspiracism borne out of the new media landscape, which they define as conspiracy without a theory. "There is no punctilious demand for proofs, no exhaustive amassing of evidence, no dots revealed to form a pattern, no close examination of the operators plotting in the shadows. The new conspiracism dispenses with the burden of explanation. Instead, we have innuendo and verbal gesture... What validates the new conspiracism is not evidence but repetition... The effect of conspiracist thinking once it ceases to function as any sort of explanation is delegitimation" (pg. 3).

Domestic propaganda efforts abound in the new media landscape (Shin et al., 2018), sometimes originating with inaccurate online rumors that resurface repeatedly to an extent that accurate rumors do not. On Twitter, such misinformation is often repackaged and brought back to life strategically by partisan news organizations, hence transforming misinformation into disinformation (Shin et al., 2018). Moreover, misinformation can spread "farther, faster, deeper, and more broadly than the truth" (Vosoughi, Roy, \& Anal, 2018, pg. 1146; but see Guess, Nagler, \& Tucker, 2019 for work that shows that the sharing of misinformation during the 2016 election was rare). Recognition of the potential negative consequences of belief in misinformation and conspiracy theories (Douglas et al. 2019; Kuklinski et al., 2000) has also spurred research that explores the effectiveness of content aimed at combating misinformation, 
through either inoculation or "prebunking” (Lewandowsky \& van der Linden 2021), refutations from unlikely sources (Berinsky 2015), or through correcting misinformation one it has taken hold (e.g., Chan et al., 2017; Garrett, Nisbet, \& Lynch, 2013; Nyhan et al. 2020; Ophir et al. 2020; Trujillo et al., 2021; Walter et al. 2020; Young et al., 2018)

\section{The "Effects"}

Lastly, we review scholarship that demonstrates how the changing media landscape necessitates a reimagining of the effects of political communication, focusing on message processing, cognitive theories of media effects (specifically, agenda-setting), and political polarization.

Message Processing. Dual process models of information processing like the Elaboration Likelihood Model (Petty \& Cacioppo,1986) and the Heuristic Systematic Model (Chaiken, 1980) continue to dominate cognitive psychological approaches to political communication processing and effects (see Chapter 17 for a thorough discussion of dual process theories). Both models conceptualize individual motivation (see Chen, Duckworth, \& Chaiken, 1999) and ability as the factors that determine whether individuals are thoughtful and analytical as they process information, or if they are guided by heuristic cues, like source credibility (Sundar, 2008), attractiveness, or aesthetic features of the message. The notion that information processing is contingent on an individual's motivation and ability to engage thoughtfully with a message is crucial when considering the effects of political messages embedded within decentralized networked ecosystems that are also fragmented and micro-segmented.

Writing in 1995, Negroponte introduced the concepts of "push" and "pull" media to capture the distinction between old broadcast media that were "pushed" out to people versus digital media that people can select and "pull" towards themselves. "Being digital will change 
the nature of mass media from a process of pushing bits at people to one of allowing people (or their computers) to pull at them," he wrote(1995, p. 84). Building on the concepts of "push" and “pull” media, Holbert, Garrett, \& Gleason (2010) explicate the implications of digital "pull” media for cognitive processing. They propose that the logics of old mass "push" media were likely to be met by audience members comparatively lower in motivation to process media content (because there was less opportunity for content selection), hence resulting in a greater likelihood of peripheral and heuristic message processing. But with fragmentation, choice, and interpersonally-contextualized media experiences, users are guided by a motivation and ability to "pull" relevant, interesting, socially-beneficial content towards them. Holbert et al. (2010) argue this means media content is likely to be engaged with thoughtfully, or centrally, hence resulting in attitudes that are resistant and longer-lasting, or - if scrutiny results in counterargumentaion less attitude change and more message resistance. These dynamics also complicate the historical distinction between media exposure and media attention (Chaffee \& Schleuder, 1986; Semetko et al, 1992), as the decision to select and "pull" content towards oneself in a high choice media environment might itself be indicative of interest in and attention to that content.

Since political messaging and news are now embedded within social networks, interpersonal dynamics ought to shape motivation and ability to thoughtfully engage with information content as well. In the context of public opinion towards an unfamiliar issue (nanotechnologies), Ho, Scheufele, \& Corley (2013) found that people are mainly guided by heuristic cues when processing news, yet interpersonal communication changes these dynamics. The link between cognitive elaboration and public opinion towards nanotechnologies was contingent on interpersonal communication on the topic. In an examination of how people process and learn from information obtained through news versus through social contacts, 
Carlson (2019) found people learned more through news - except when the social contact was like-minded and knowledgeable, in which case individuals learned as much through the social contact as they did through news.

Looking at the effects of online comments on news story processing and engagement, message relevance (related to processing motivation) matters. User comments focused on a specific dimension (regionalism) of a news story shape audience recall and persuasion, especially for individuals for whom that dimension (regionalism) is especially salient (e.g., those highest in regional self-identity; Lee, Kim, \& Cho, 2017). Users' perceptions of the credibility of news stories are also affected by the valence of user comments, especially for users to whom the content is relevant (Winter, Bruckner, \& Kramer, 2015). Yet, while social media users consider their friends more credible than news organizations in general, they still rate specific news articles as more credible when shared by a news organization than by a friend (Tandoc, 2018).

When it comes to political expression and information sharing decisions in online contexts, experimental work indicates that motivation to thoughtfully process a message might be overshadowed by reputational and social motivations (Winter, 2020). Winter (2020) found that users who anticipated writing on social media about a given news article were more likely to be motivated by impression management than by the quality of the arguments in the article itself. Whereas people express themselves politically online for social and persuasion-related reasons (see Eveland, Morey, \& Hutchens, 2011), the effects of political expression on cognitive elaboration and subsequent political participation is contingent on which motivations are guiding them, with persuasion motivations a bigger driver of elaboration and participation (compared to social motivations), mediated by news-seeking behaviors (Yoo, Kim, \& Gil de Zuniga, 2017). 
Finally, the notion that exposure to "pull" media might reflect increased motivation to engage in cognitive elaboration and argument scrutiny may itself be complicated by factors related to the physical technologies themselves. Many users, especially younger users, engage in "second screen" or "dual screen" behaviors (see Gil de Zuniga \& Liu, 2017), typically involving the use of a smartphone or tablet while (or immediately following) consuming other media, such as television or streaming content (see Nee \& Barker, 2020). Such dual screen activities during news or political debates viewing can increase cognitive load and reduce news processing, recall, and comprehension (Van Cauwenberge, Schaap, \& Van Roy, 2014). However, research also points to emotional and social benefits of second screen behaviors, including building feelings of community and learning the opinions of others (Nee \& Barker, 2020), as well as political benefits, including seeking additional information, sharing information and expanding knowledge in ways that fuel further political engagement (Chadwick, O'Loughlin, \& Vaccari, 2017; Vaccari, Chadwick, \& O’Loughlin, 2015).

Increased reliance on smartphones, tablets and computers for news (see Shearer, 2021) has spurred scholars to study the impact of screen size and mobile news features on cognitive processing, attention, and learning, with disappointing results. Dunaway et al (2018) demonstrate that although shifts in news norms and production routines for mobile devices might increase access to news, they may also erode regular in-depth engagement with news stories. Their eyetracking studies illustrate that even when users perceive that they are paying attention to news content on mobile devices, that attention is lower than it is on computers. Additional lab studies reveal that video news, when consumed on mobile, elicits lower psychophysiological responses than when consumed on larger screens, hence indicating less cognitive engagement with - and arousal to - news programming on mobile (Dunaway \& Soroka, 2021). 
Agenda-Setting Revisited. Again. And Again and Again. The decentralized control of political media, networked logics of digital spaces, and reduced gatekeeping authority of traditional news organizations all change the context within which cognitive theories of media effects occur. Take agenda-setting, for instance. Although we still see evidence of legacy news outlets shaping the agendas of the public (Tran, 2013), agenda setting effects are far smaller among those who rely on alternative and online information sources (Shehata \& Stromback, 2013). Feezell (2017) found that people had their agendas shaped by "incidentally-encountered" stories on social media, with the strongest agenda setting effects found among those lowest in political interest.

Meanwhile, the story selection decisions of journalists and editors are themselves influenced by online and alternative content as well, as news organizations include stories and events that have circulated through social media and niche outlets (Jacobson, 2013). Gilardi et al (2021) found that the news' agenda was set by the social media agenda of politicians and political organizations, and their agendas were, in turn, shaped by the news and by each other. This "intermedia agenda setting" research (McCombs, 2004), exploring who is setting whose agenda, illustrates that although traditional news is still a dominant setter of the public's agenda (Djerf-Pierre \& Shehata, 2017), Twitter - especially media-related Twitter - helps to set the agenda of mainstream news (Harder, Sevenans, \& Van Aelst, 2017; Valenzuela, Puente, \& Flores, 2017), especially in the context of breaking news stories (Se \& Borah, 2019). Additionally, partisan news outlets are driving the agendas of some traditional legacy news outlets (Vargo \& Guo, 2017); by covering stories that serve their ideological perspective, they indirectly pressure mainstream outlets to cover those stories as well. These complex reciprocal agenda-setting dynamics have significant consequences, especially if the online content shaping 
the agenda of a news organization is false, something that is particularly likely for partisan news organizations (Guo \& Vargo, 2020; Vargo, Guo, \& Amazeen, 2017).

Networked and intermedia dynamics permit bottom-up agenda-setting processes that may empower issue publics and activists (Luo, 2014; Su \& Hu, 2020). With the public's agenda constructed through these complex relationships, the nature of Downs (1972) "issue attention cycle" has changed. The "alarmed discovery" phase that used to catapult the public into action is no longer driven by the media's agenda alone, but also through interpersonal discussion and mobilization through social media (Wang \& Guo, 2018; Zhang et al., 2017). Issue publics mobilized through "hashtag activism" help shape media and policy agendas, framing issues from racial justice (Bonilla \& Rosa, 2015; Yang, 2016) to gendered terrorism attacks (Carter Olson, 2016) to sexual harassment (Xiong, Cho, \& Boatwright, 2019).

In the largely homogeneous, mass-audience-oriented media system of the 1970s, articulating a distinction between signaling to people what issues to pay attention to versus persuading people to think a certain way made sense. But by 2005 , as that distinction was becoming obsolete, McCombs circled back again. "The media not only can be successful in telling us what to think about," he wrote, "they also can be successful in telling us how to think about it" (McCombs, 2005, p. 546). So called "attribute agenda setting" or "second level agenda setting" is similar to "framing" in that it involves elements of a news story being made more salient in ways that influence how audiences think about the issue (Entman, 1993). With fragmented partisan media outlets reporting on stories in ways that complement their networks' ideological leanings, attribute agenda setting (Muddiman, Stroud, \& McCombs, 2014) and framing have become an essential part of contemporary media effects research. Recent studies illustrate how partisan news frames shape viewer perceptions of issues ranging from immigration 
(Gil de Zuniga, Correa, \& Valenzuela, 2012) to climate change (Feldman et al. 2012), to COVID vaccines (Jamieson \& Albarracin, 2020; but see also Trujillo \& Motta, 2021 for data from 144 countries indicating that mere internet access itself is related to vaccine hesitancy) to election integrity and voter ID laws (Wilson \& Brewer, 2013).

Political Polarization. The new media landscape is both interpersonal and identityreinforcing by design. As discussed above, media and political elites and non-elites alike have incentives to create emotion-laden content (whether it be information, misinformation, or disinformation) that taps into the intended audience's increasingly interconnected (Mason 2018) social and political identities. And audiences have a greater ability than ever before to selectively expose themselves to content that meets their informational, entertainment, identity-reinforcing, and/or attitude-reinforcing needs. This perfect storm of content production and content selection is what Slater $(2007 ; 2015)$ calls a reinforcing media spiral - social identity drives media behaviors in ways that reinforce those identities. The "spiral" aspect of these relationships stems from the recursive dynamics between exposure and polarization that numerous scholars have highlighted (Prior, 2013; Stroud, 2010). Such studies point both to media contributing to polarization, and to polarization fueling exposure to like-minded media. Given the central role that identity plays in political polarization (Iyengar, Sood, \& Lelkes, 2017), recent research has explored the impact of political communication in this new media environment on both attitude and affective polarization (see Tucker et al. 2018 for a comprehensive review of the role that misinformation plays in this process).

With regard to attitude polarization, Song and Boomgaarten (2017) use an agent-based modeling approach to demonstrate the role of interpersonal (dis)agreement in the reinforcing media spiral process, concluding that, "reciprocal dynamics between attitude polarization and 
attitudinally congruent partisan media exposure over time critically hinge on the attitudinal composition of one's discussion network and contextual variations in which such media exposure occurs" (p. 18). Feldman et al. (2014) use a two-wave panel study to test the reinforcing spirals model in the context of attitudes about global warming, finding evidence for an "ongoing, reinforcing cycle in which media use influences beliefs, and these beliefs then affect subsequent media use, which, in turn, reinforces beliefs" (p. 603). And Lee et al. (2014) find that the positive relationship between social network homogeneity and attitude polarization is strongest among people who engage in political discussions more often than those who do not. These polarization effects are also moderated by the variation in affordances of different social media platforms (e.g., Facebook, Twitter, and WhatsApp; Yarachi, Baden, and KliglerVilenchik, 2020). In her book, Niche News, Stroud (2011) demonstrates how partisan selective exposure, exacerbated by the proliferation of partisan media outlets, can simultaneously increase (not necessarily equitable) political participation and contribute to attitude polarization and fragmented interests. Pointing to the potential deleterious effects of this process for democracy, Stroud (2011, p. 10) argues that: "the onslaught of diverse partisan media outlets may undercut the development of common goals... Without a shared issue agenda, allocation of limited resources, such as time and money, become more difficult.” Arceneaux and Johnson (2013) argue that some of the polarizing effects demonstrated in this literature are a methodological artifact - experiments that force exposure to pro- or anti-attitudinal content. In a series of innovative experiments, Arceneaux and Johnson (2013) demonstrate that the polarizing effects of exposure to partisan media sources are limited by audience characteristics and the available content choices (i.e., whether people can opt out of news/political content altogether). Prior's (2013) work indicates that attitude polarization from selective media exposure is limited to those 
individuals who are highly politically interested and engaged, a subpopulation that is arguably more likely to wield political influence.

Recent research also points to the role of digital algorithms and curated information flows in exacerbating political divisions (Cho et al. 2020). In contrast, Munger and Phillips' (2020) analysis of right-wing political content on YouTube challenges the notion that algorithms themselves cause polarization and/or radicalization. They propose a supply and demand framework for analyzing the impact of political content on YouTube. Rahter than the supply of right wing YouTube Content turning moderates into radicals (in a top-down, "hypodermic" way), the authors argue for the central role of content demand in this process: "the true threat posed by some right-wing content on YouTube is the capacity for creators to draw communities of committed viewers that mutually create and reinforce radical political canons, including some that promote hatred. There is a cap on how much news media a person can consume in a given day; YouTube has dramatically increased the number of distinct political communities which are able to hit that content cap" (pg. 3). Although more research is needed to pin down the precise nature of the causal impact of algorithms, it is clear that dominance of algorithms and curated flows of information in the new media environment necessitate methodological advances that can distinguish the effects of selective exposure (demand), on the one hand, and selected (e.g., by algorithms) exposure (supply), on the other (Thorson et al. 2019; Thorson \& Wells, 2016).

While attitude polarization concerns the shifting of policy positions towards partisan extremes, affective polarization refers to the rise in negative attitudes towards the opposing political party. In the latter context, emerging evidence highlights the role of media exposure, with subtle and contingent effects of media as a function of audience and content characteristics. 
For example, Druckman et al. (2019) find that the relationship between exposure to partisan incivility and positive affect towards, and trust in, the party of the source of the incivility is moderated by whether the content is pro- or counter-attitudinal; such exposure is depolarizing for in-party members, but polarizing for out-party members Work by Hasell and Weeks (2016) illustrates the implications of affective polarization beyond mere attitudes, finding that exposure to pro-attitudinal content increases anger towards the opposing party, which, in turn, increases the likelihood of sharing the content. Lelkes, Sood, \& Iyengar (2017) find that access to broadband internet increases negative affect towards out-partisans, likely due to the increased exposure to partisan media that broadband affords. in her book, Frenemies, Settle (2018) proposes the END framework of social media interaction to conceptualize the political psychological process that exacerbates polarization in this new media landscape. "END refers to the characteristics of a subset of content that circulates in a social media ecosystem: a personalized, quantified blend of politically informative expression, news, and discussion seamlessly interwoven into a wider variety of socially informative content" (p. 50). Using this framework, Settle (2018) illuminates the ways in which even incidental exposure to and interaction with political (and, importantly, nonpolitical) content increases identity salience and has downstream effects on social inferences and affective polarization. All told, media are implicated in both attitudinal and affective polarization, in complex ways that are contingent on audience psychology and platform characteristics.

\section{Advances in Political Communication Research Methods}

The changing media landscape has also led to innovations in research methods from ones focused primarily on studying the unidirectional impact of "the"(singular) media on individuals 
(as individuals) to ones that enable researchers to study the networked, bidirectional, interpersonal, and fragmented nature of political communication causes and effects.

New Sampling Platforms. In recent years, scholars have increasingly relied on cheap online participant samples, including Amazon's Mturk and Prolific,often for experiments, panels, and real-time online experiments (Christenson \& Glick, 2013). But reliance on these samples often presents problems related to sample representativeness that pose unique problems for political communication researchers. Mturk samples, for example, tend to lack older participants (see Brewer, Morris, \& Piper, 2016), and the few older participants they do include are far higher in "digital literacy" (Hargittai, 2002; 2005) than older non-Mturkers. Such self-selection presents generalizability problems when looking at political and communication dynamics that vary with age or digital literacy (Munger et al (2020), like the susceptibility to - or willingness to share mis and disinformation (Guess \& Munger, 2020).

Digital Trace Data. Whereas new technologies gave rise to cheap sampling platforms like Mturk, they also ushered in an era of "big data" and "computational social science" in the field of political communication (Stroud \& McGregor, 2018). Digital trace data from social media and other online behaviors has been used to study social networks and political behavior (Zuckerman, 2005), agenda setting effects (Conway, Kenski, \& Want, 2015; Neuman et al, 2014), and information flows (Wells, \& Thorson, 2017). While the potential to study previously unmeasurable phenomena (Watts, 2011) is revolutionary for the field of political communication (Bode, 2018), scholars urge that the temptation to fetishize data over theory should be resisted (Gonzalez-Bailon, 2013). Gonzalez-Bailon reminds us, "Social science has the theoretical tradition to build a context for these data, point to the right mechanisms of the dynamics analyzed, and build credible interpretations - which is as important as having access to vast 
amounts of information and cutting-edge methods" (p. 159). Combinations of survey research with digital trace data can help center theory within such big data approaches (Choi, 2020; Stier et al., 2019).

And although social media data accurately predicts election outcomes and the results of empirical public opinion surveys (Ceron et al. 2014), recent studies of the users of the various tech platforms suggest we should use caution as we consider who these people are and who they are not (Auxier \& Anderson, 2021). For example, Pew reports that while $71 \%$ of $18-29$ year olds use Instagram and $42 \%$ use Twitter, among adults 65 and older, these numbers drop to $13 \%$ and $7 \%$, respectively. There are also important racial and ethnic differences, with $46 \%$ of Hispanics reporting using What'sApp, compared to $23 \%$ of black respondents, and $16 \%$ of whites. Twitter, in particular, is unique in ways that have implications for political communication research, as its users make less money, are less educated, and less likely to live in rural areas compared to nonusers (Auxier \& Anderson, 2021). Freelon urges scholars to take into account the technical design, terms of service, social context, and potential for misrepresentation introduced by particular platforms as they select digital trace data sources (Freelon, 2018). Through a nuanced understanding of the "patterns and dynamics" underlying trace data (Jungherr, 2015) scholars can contextualize findings in a transparent and meaningful way.

Automatic Coding Techniques. Advances in computational methods have also opened the doors for large-scale studies of the content of - and trends in - political information and media content (see Grimmer \& Stewart, 2013). These include large-scale sentiment analysis to capture the extent of affect in news (Young \& Soroka, 2012), the extent of news content on Twitter (Malik \& Pfeffer, 2016), the misinformation ecosystem (Vargo, Guo, \& Amazeen, 2016), and the content of comments sections on news websites (Muddiman, 2018). As automated big data 
approaches to the study of political information increase in number, we again find warnings from those seeking to keep theory at the center of political communication research. Reliance on automated techniques might lack a nuanced understanding of language and cultural symbols. They may also incentivize a "data mining" approach where trends are identified first and post hoc explanations to account for those trends are concocted later. Such warnings include recommendations for the integration of crowd-coding (Haselmayer \& Jenny, 2017) and manual coding into computer automated coding techniques (Lewis, Zamith, \& Hermida, 2013; Zamith \& Lewis, 2015). Whereas some (Pal \& Gonawela, 2017) make the case for "a return to small data" in content analysis with the integration of qualitative and interpretive approaches, others implore scholars to return to interpretive, mixed methods approaches to the study of political communication as a whole to "build theory and analyze social life" (Karpf et al, 2015).

Measuring Exposure to Political Communication. The most important construct in the field of political communication research is also the most hotly contested: exposure to media content (see de Vreese \& Neijens, 2016; Fishbein \& Hornik, 2008). People are unreliable reporters of their own media use (see Parry et al, 2021; Prior, 2009a) and tend to overestimate their exposure to programming that they do, indeed, consume (Jurgens, Stark, \& Magin, 2020; Prior, 2009b). But, the validity of self-reported exposure measures also varies with question wording (see Smith \& Neijens, 2011 for a review), with self-reported exposure to specific sources more reliable than general exposure measures (Scharkow, 2019). Self-reported measures are also complicated by the fact that users multitask with media (Foehr, 2006), including engaging in "second screen” viewing (Van Cauwenberge, Schaap, \& Van Roy, 2014).

Such issues raise the question of measuring exposure through more "passive" approaches through recording technologies, or digital trace data, as discussed above (de Vreese \& Neijens, 
2016). Yet, media exposure obtained through tracking devices that users agree to install on their devices is not unbiased either (Jurgens, Stark, \& Magin, 2020), both in terms of the kind of people who would allow themselves to be tracked in this way, and in the behavioral changes people might make because their media behaviors are being tracked. When comparing selfreported and logged smartphone use in their effects on aspects of social behavior and well-being, (Jones-Jang et al, 2020) found that the self-reported measures underestimated the strength of these relationships, hence suggesting that the size of media effects in reality might be much larger than self-reports would suggest. Jerit et al. (2016) propose a hybrid "benchmark" approach to compare experimentally manipulated exposure to self-reported exposure, and then examine question-wording options to understand which produces the most "accurate" self-reported measure of exposure.

Media fragmentation increases individuals' opportunities to selectively choose - or avoid - exposure to media content. But on social media platforms like Facebook, exposure to politically relevant content - just incidentally through our newsfeeds - is shaped by our own behaviors, our friends' behaviors, behaviors of news organizations, advertisers, and platform algorithms (Thorson \& Wells, 2016). Our exposure behaviors, therefore, are more akin to “exposure opportunities," that are constrained by media context. Thorson et al. (2019) use survey data combined with respondents' individually downloaded Facebook data archives to mimic Facebook's understanding of users' political interest and to capture how Facebook had labeled individuals for advertisers (politically interested or not). Their results show that individuals "algorithmic identity, as categorized by Facebook, has an independent relationship to content exposure above and beyond user-reported levels of topical interest" (p. 193). If Facebook decides you are politically interested, you get more political content in your feed. If not, you don't. Such 
constraints in media choice must be factored into conceptualizations of "media exposure" and into theoretical models of effects.

\section{Conclusion}

We argue in this chapter that the conventional theories and processes at the core of the field of political communication are rooted in assumptions that no longer hold and contexts that no longer exist. Today's media are decentralized, interpersonal, horizontal, and networked, a combination that has sweeping implications for the ways that individuals use, interact with, and are used by media. We focused here on two main changes in media experiences that upend assumptions of the field: 1) Individuals today encounter socially- and interpersonallycontextualized messaging and 2) this is occurring within a system predicated on the economics and logics of micro-segmentation. We assert that these are qualitative shifts. In other words, this is not simply a story about more outlets, a blurring of entertainment and information, or more partisan media content. Instead, this is a story about how shifts in fundamental aspects of message production, dissemination, consumption, and selection change the essence of the theoretical mechanisms at play within the field of political communication. And these new mechanisms are highly social, interpersonal, psychologically contingent and mediated. They will require creative integration of political psychology - from the study of the drivers of message development and dissemination, to research on the nature of message selection, processing, and effects.

We use Lassewll's (1948) "who said what to whom, with what effect" model to illuminate the ways in which changes in the logics and economics of media and digital technologies disrupt traditional political communication theory. Political communication is no 
longer unidirectional and vertical. The who is now virtually everyone (and, with algorithms, perhaps even "everything"), upending the notion of "gatekeepers" and broadening our conceptualization of the channels of political communication. The who is also acting in a socially-networked, group-identity-driven context in which the traditional message receivers (the whom) are interconnected with others who might also be message producers and message sharers (the old who). Meanwhile, the social media landscape provides these individuals with more opportunities to be active and effective seekers of messaging. Yet these seemingly empowering characteristics of digital technologies also facilitate and incentivize the strategic curation and packaging of content by message producers (at both the elite and mass level); message producers seeking to attract, engage, persuade, and mobilize their intended audience. Hence, today's whom has both more choice to select content that suits their needs and goals and, counterintuitively, less agency (due to strategic message development, algorithms, and curated information flows), leading to concerns about echo chambers and polarization, most notably on the margins where the effects of extremism are the most devastating.

Because the economics of media systems have adapted to the changing who and whom, the content of political communication (the what) has also changed in its composition, including the proliferation of hyper-emotional and uncivil content, increasing misinformation and disinformation, but also interpersonal political communication and socially-networked political communication experiences. With these evolving whos, whats and whoms, come advances in our understanding of the complex mechanisms at play within and between our communication experiences (like the Reinforcing Media Spirals Model, or Curated Information Flows), which allow us to rethink the types of politically-relevant effects we might find (e.g., message processing, agenda-setting, or political polarization). 
Today's media ecosystem creates new and expanded opportunities for the role of political psychology within the field of political communication: in media selection behaviors, in the moderation and mediation of effects processes, and in the anticipation of individual psychology by message producers and disseminators. As these processes become known to - and anticipated by - message producers, they inform the deliberate construction and curation of the very media content people encounter. This is what we mean when we say audience psychology is now "baked into" media products and messaging strategies. As such, the political communication of tomorrow must tackle thorny questions about what these changes in the information environment mean for the role that political psychology plays in the study of political communication. What are the effects of the fact that psychology is now baked into message construction and dissemination to attract audiences by exploiting socio-political identities and emotions? And how, and under what conditions, does the interpersonally-networked media environment increase identity salience (e.g., through selective or incidental exposure) and incentivize the production and sharing of mis- and disinformation and further fragment and polarizes society, on the one hand, or (and) open up new avenues for political consciousness-raising, political participation, and collective action on the other? 


\section{References}

Aarøe, L., \& Petersen, M. B. (2020). Cognitive biases and communication strength in social networks: the case of episodic frames. British Journal of Political Science, 50(4), 1561-1581.

Abbate, J. (2000). Inventing the Internet. Boston: MIT Press.

Albertson, B. \& Gadarian, S. (2015). Anxious Politics: Democratic Citizenship in a Threatening World. New York: Cambridge University Press.

Ali, S. R., \& Fahmy, S. (2013). Gatekeeping and citizen journalism: The use of social media during the recent uprisings in Iran, Egypt, and Libya. Media. War \& Conflict, 6(1), 55-69.

Altheide, D. L., \& Snow, R.P. (1979). Media Logic. Beverly Hills: Sage.

Anspach, N. M. (2017). The new personal influence: How our Facebook friends influence the news we read. Political Communication, 34(4), 590-606.

Antony, M. G., \& Thomas, R. J. (2010). This is citizen journalism at its finest': YouTube and the public sphere in the Oscar Grant shooting incident. New Media \& Society, 12(8), 1280-1296.

Arceneaux, K., \& Johnson, M. (2013). Changing minds or changing channels? Partisan news in an age of choice. Chicago: University of Chicago Press.

Auxier, B. \& Anderson, M. (2021). Social media use in 2021. Pew Research Center. https://www.pewresearch.org/internet/2021/04/07/social-media-use-in-2021/

Bacovsky, P. (2021). Gaming alone: Videogaming and sociopolitical attitudes. New Media \& Society, 23(5), 1133-1156.

Bakker, B. N., Schumacher, G., \& Rooduijn, M. (2021). The populist appeal: Personality and antiestablishment communication. The Journal of Politics, 83(2), 589-601.

Bakshy, E., Messing, S., \& Adamic, L. A. (2015). Exposure to ideologically diverse news and opinion on Facebook. Science, 348(6239), 1130-1132.

Barone, D. F., Maddux, J. E., \& Snyder, C. R. (1997). Social Cognitive Psychology: History and Current Domains. New York: Springer Science + Business Media.

Baum, M. A., Groeling, T. J. (2008). New media and the polarization of American public discourse. Political Communication, 25:345-65.

Baum, M. A., \& Jamison, A. S. (2006). The Oprah effect: How soft news helps inattentive citizens vote consistently. The Journal of Politics, 68(4), 946-959.

Baym, G. (2017). Journalism and the hybrid condition: Long-form television drama at the intersections of news and narrative. Journalism, 18(1), 11-26. 
Becker, A. B., \& Bode, L. (2018). Satire as a source for learning? The differential impact of news versus satire exposure on net neutrality knowledge gain. Information, Communication \& Society, 21(4), 612-625.

Bennett, W. L. (1998). 1998 Ithiel De Sola Pool lecture: The uncivic culture: Communication, identity, and the rise of lifestyle politics. PS: Political Science and Politics, 31(4), 741-761.

Bennett, W. L. (2016). News: The Politics of Illusion. Chicago: University of Chicago Press.

Berger, J. \& Milkman, K. (2012). What makes online content viral? Journal of Marketing Research, 49, 192-205.

Bergman, S. M., Fearrington, M. E., Davenport, S. W., \& Bergman, J. Z. (2011). Millennials, narcissism, and social networking: What narcissists do on social networking sites and why. Personality and Individual Differences, 50(5), 706-711.

Berinsky, A. J. (2015). Rumors and health care reform: Experiments in political misinformation. British Journal of Political Science, 47, 241-262.

Bineham, J. L. (1988). A historical account of the hypodermic model in mass communication. Communication Monographs, 55, 230-246.

Blumer, H. (1951). The field of collective behavior. In Lee, A.M. (ed.), Principles of Sociology, New York, Barnes and Noble.

Blumler, J. G., \& Kavanagh, D. (1999). The third age of political communication: Influences and features. Political Communication, 16(3), 209-230.

Bode, L. (2018). Everything old is new again: big data and methodological transparency. In Shroud, N.J. \& McGregor, S. C. (eds), Digital Discussions: How Big Data Informs Political Communication (pp. 36-49). New York: Routledge.

Bonilla, Y., \& Rosa, J. (2015). \# Ferguson: Digital protest, hashtag ethnography, and the racial politics of social media in the United States. American Ethnologist, 42(1), 4-17.

Borah, P. (2013). Interactions of news frames and incivility in the political blogosphere: examining perceptual outcomes. Political Communication, 30(3), 456-473.

Bossetta, M. (2018). The digital architectures of social media: Comparing political campaigning on Facebook, Twitter, Instagram, and Snapchat in the 2016 US election. Journalism \& Mass Communication Quarterly, 95(2), 471-496.

Boukes, M. (2021). Episodic and thematic framing effects on the attribution of responsibility: The effects of personalized and contextualized news on perceptions of individual and political 
responsibility for causing the economic crisis. The International Journal of Press/Politics, January, 1-21.

Boutyline, A. \& Willer. R. 2017. The social structure of political echo chambers: Variation in ideological homophily in online networks. Political Psychology, 38(3): 551-569.

Brader, T. (2006). Campaigning for Hearts and Minds: How Emotional Appeals in Political Ads Work. Chicago: Chicago University Press.

Brady, W., Willis, J., Jost, J. T., Tucker, J. A., \& Van Bavel, J. (2017). Emotion shapes diffusion of moral content in social networks. Proceedings of the National Academy of Sciences. 114(28): $7313-7318$.

Brewer, P. R., Young, D. G., Lambe, J. L., Hoffman, L. H., \& Collier, J. (2018). Seize your moment, my lovely trolls: News, satire, and public opinion about net neutrality. International Journal of Communication, 12, 23.

Brewer R., Morris, M.R. \& Piper, A.M. (2016) Why would anybody do this? Understanding older adults' motivations and challenges in crowd work. In: Proceedings of the $2016 \mathrm{CHI}$ Conference on human factors in computing systems, San Jose, USA, 7-12 May 2016. Association for Computing Machinery, pp.2246-2257.

Cantril, H., Gaudet, H., \& Herzog, H. (1940). The Invasion from Mars. Princeton: Princeton University Press.

Cao, X. (2008). Political comedy shows and knowledge about primary campaigns: The moderating effects of age and education. Mass Communication \& Society, 11(1), 43-61.

Cappella, J. N. (2017). Vectors into the future of mass and interpersonal communication research: Big data, social media, and computational social science. Human Communication Research, 43(4), 545-558.

Cappella, J. N. \& Jamieson, K.H. (1997). Spiral of Cynicism: The Press and the Public Good. New York: Oxford University Press.

Cappella, J. N., Kim, H. S., \& Albarracín, D. (2015). Selection and transmission processes for information in the emerging media environment: Psychological motives and message characteristics. Media Psychology, 18(3), 396-424.

Carlson, T. N. (2019). Through the grapevine: Informational consequences of interpersonal political communication. American Political Science Review, 113(2), 325-339.

Carlson, M., Robinson, S., \& Lewis, S. (2021). News after Trump: Journalism's Crisis of Relevance in a Changed Media Culture. Oxford: Oxford University Press. 
Carr, D. J., Barnidge, M., Lee, B. G., \& Tsang, S. J. (2014). Cynics and skeptics: Evaluating the credibility of mainstream and citizen journalism. Journalism \& Mass Communication Quarterly, 91(3), 452-470.

Carter Olson, C. (2016). \# BringBackOurGirls: Digital communities supporting real-world change and influencing mainstream media agendas. Feminist Media Studies, 16(5), 772-787.

Ceron, A., Curini, L., Iacus, S. M., \& Porro, G. (2014). Every tweet counts? How sentiment analysis of social media can improve our knowledge of citizens' political preferences with an application to Italy and France. New Media \& Society, 16(2), 340-358.

Chadwick, A. (2017). The Hybrid Media System: Politics and Power. Oxford: Oxford University Press.

Chadwick, A., O'Loughlin, B., \& Vaccari, C. (2017). Why people dual screen political debates and why it matters for democratic engagement. Journal of Broadcasting \& Electronic Media, 61(2), 220-239.

Chae, J. (2021). YouTube makeup tutorials reinforce postfeminist beliefs through social comparison. Media Psychology, 24(2), 167-189.

Chaffee, S. H., \& Metzger, M. J. (2001). The end of mass communication? Mass Communication \& Society, 4(4), 365-379.

Chaffee, S. H. \& Schleuder, J. 1986. Measurement and effects of attention to media news. Human Communication Research, 13,76-107.

Chaiken, S. (1980). Heuristic versus systematic information processing and the use of source versus message cues in persuasion. Journal of Personality and Social Psychology, 39(5), 752756

Chan, M. S., Jones, C. R., Jamieson, K. H., Albarracín, D. (2017). Debunking: a meta-analysis of the psychological efficacy of messages countering misinformation. Psychological Science, 28(11), 1531-1546

Chen, S., Duckworth, K., Chaiken, S. 1999. Motivated heuristic and systematic processing. Psychological Inquiry, 10(1): 44-49.

Chen, Z., \& Chan, M. (2017). Motivations for social media use and impact on political participation in China: A cognitive and communication mediation approach. Cyberpsychology, Behavior, and Social Networking, 20(2), 83-90.

Choi, S. (2020). When digital trace data meet traditional communication theory: Theoretical/methodological directions. Social Science Computer Review, 38(1), 91-107. 
Cho, J., Ahmed, S., Hilbert, M., Liu, B., \& Luu, J. (2020). Do search algorithms endanger democracy? An experimental investigation of algorithm effects on political polarization. Journal of Broadcasting \& Electronic Media, 64(2), 150-172.

Christenson, D. P., \& Glick, D. M. (2013). Crowdsourcing panel studies and real-time experiments in Mturk. The Political Methodologist, 20(2), 27-32.

Cleridou, K., \& Furnham, A. (2014). Personality correlates of aesthetic preferences for art, architecture, and music. Empirical Studies of the Arts, 32(2), 231-255.

Conway, B. A., Kenski, K., \& Wang, D. (2015). The rise of Twitter in the political campaign: Searching for intermedia agenda-setting effects in the presidential primary. Journal of ComputerMediated Communication, 20(4), 363-380.

Cui, C., Yang, W., Shi, C., Wang, M., Nie, X., \& Yin, Y. (2020). Personalized image quality assessment with Social-Sensed aesthetic preference. Information Sciences, 512, 780-794.

De Vreese, C. H., Esser, F., Aalberg, T., Reinemann, C., \& Stanyer, J. (2018). Populism as an expression of political communication content and style: A new perspective. The International Journal of Press/Politics, 23(4), 423-438.

De Vreese, C. H., \& Neijens, P. (2016). Measuring media exposure in a changing communications environment. Communication Methods and Measures, 10, 69-80.

Dearing, J.W., Rogers, E.M. (1996). Communication Concepts 6: Agenda-Setting. Thousand Oaks: Sage Publications.

Deibert, R. J. (2019). The road to digital unfreedom: Three painful truths about social media. Journal of Democracy, 30(1), 25-39.

Djerf-Pierre, M., \& Shehata, A. (2017). Still an agenda setter: Traditional news media and public opinion during the transition from low to high choice media environments. Journal of Communication, 67(5), 733-757.

Domke, D., Shah, D. V., \& Wackman, D. B. (1998). Media priming effects: Accessibility, association, and activation. International Journal of Public Opinion Research, 10(1), 51-74.

Douglas, K. M., Uscinski, J. E., Sutton, R. M., Cichocka, A., Nefes, T., Ang, C. S., \& Deravi, F. (2019). Understanding conspiracy theories." Advances in Political Psychology, 40(1): 3-35.

Druckman, J. N., Gubitz, S. R., Levendusky, M. S., \& Lloyd, A. M. (2019). How incivility on partisan media (de)polarizes the electorate. The Journal of Politics, 81(1): 291-295.

Druckman J.N., Levendusky, M.S., \& McLain, A. (2018). No need to watch: how the effects of partisan media can spread via inter-personal discussions. American Journal of Political Science, 62(1):99-112. 
Dubois, E. \& Blank, G. (2018). The echo chamber is overstated: The moderating effect of political interest and diverse media. Information, Communication \& Society, 21:5, 729-74

Dunaway, J., \& Soroka, S. (2021). Smartphone-size screens constrain cognitive access to video news stories. Information, Communication \& Society, 24(1), 69-84.

Dunaway, J., Searles, K., Sui, M., \& Paul, N. (2018). The Move to Mobile: What's the Impact on Citizen News Attention? In Ridout, T. N. (ed), New Directions in Media and Politics (pp. 143157). New York: Routledge.

Durkheim, E. (1897). Suicide New York, Free Press.

Dylko, I., Dolgov, I., Hoffman, W., Eckhart, N., Molina, M., \& Aaziz, O. (2018). Impact of customizability technology on political polarization. Journal of Information Technology \& Politics, 15(1), 19-33.

Eady, G., Nagler, J., Guess, A., Zilinsky, J., \& Tucker, J.A. (2019). How many people live in political bubbles on social media? Evidence from linked survey and twitter data. SAGE Open. January 2019. Doi:10.1177/2158244019832705

Edgerly. S \& Thorson, K. (2020), Political communication and public opinion: Innovative research for the digital age. Public Opinion Quarterly, 84(S1), 189-194.

Entman, R. M. (1993). Framing: Toward clarification of a fractured paradigm. Journal of Communication, 43, 51-58.

Eveland Jr, W. P., Morey, A. C., \& Hutchens, M. J. (2011). Beyond deliberation: New directions for the study of informal political conversation from a communication perspective. Journal of Communication, 61(6), 1082-1103.

Faraj, S., \& Azad, B. (2012). The materiality of technology: An affordance perspective. Materiality and organizing: Social interaction in a technological world, 237, 258.

Fazio, L. (2020). Pausing to consider why a headline is true or false can help reduce the sharing of false news. Harvard Kennedy School Misinformation Review, 1(2).

Feezell, J. T. (2018). Agenda setting through social media: The importance of incidental news exposure and social filtering in the digital era. Political Research Quarterly, 71(2), 482-494.

Feldman, L., Leiserowitz, A., \& Maibach, E. W. (2011). The impact of The Daily Show and The Colbert Report on public attentiveness to science and the environment. Available at SSRN 1838730 .

Feldman, L., Maibach, E. W., Roser-Renouf, C., \& Leiserowitz, A. (2012). Climate on cable: The nature and impact of global warming coverage on Fox News, CNN, and MSNBC. The International Journal of Press/Politics, 17(1), 3-31. 
Feldman, L., Myers, T. A., Hmielowski, J. D., \& Leiserowitz, A. (2014). The mutual reinforcement of media selectivity and effects: Testing the reinforcing spirals framework in the context of global warming. Journal of Communication, 64(4), 590-611.

Feldman, L., \& Young, D. G. (2008). Late-night comedy as a gateway to traditional news: An analysis of time trends in news attention among late-night comedy viewers during the 2004 presidential primaries. Political Communication, 25(4), 401-422.

Fishbein, M., \& Hornik, R. (2008). Measuring media exposure: An introduction to the special issue. Communication Methods and Measures, 2(1-2), 1-5.

Flaxman, S., Goel, S., \& Rao, J. M. (2016). Filter bubbles, echo chambers, and online news consumption. Public Opinion Quarterly, 80(S1), 298-320.

Fletcher, R., \& Nielsen, R. K. (2018). Are people incidentally exposed to news on social media? A comparative analysis. New Media \& Society, 20(7), 2450-2468.

Florini, S. (2014). Tweets, tweeps, and signifyin' communication and cultural performance on "Black Twitter." Television \& New Media, 15(3), 223-237.

Foehr, U. G. (2006). Media multitasking among American youth: Prevalence, predictors, and parings. Menlo Park: The Hendry J. Kaiser Family Foundation

Freelon, D. (2018). Inferring individual-level characteristics from digital trace data: Issues and recommendations. In Shroud, N.J. \& McGregor, S. C. (eds), Digital Discussions: How Big Data Informs Political Communication (pp. 96-110). New York: Routledge.

Fröhlich R., Quiring O., \& Engesser S. (2012). Between idiosyncratic self-interests and professional standards: A contribution to the understanding of participatory journalism in Web 2.0. Results from an online survey in Germany. Journalism, 13(8):1041-1063.

Garrett, R. K. (2009). Echo chambers online? Politically motivated selective exposure among Internet news users. Journal of Computer-Mediated Communication, 14(2), 265-285.

Garrett, R. K. (2017). The "echo chamber" distraction: Disinformation campaigns are the problem, not audience fragmentation. Journal of Applied Research in Memory and Cognition, $6(4), 370-376$

Garrett, R. K., Carnahan, D., \& Lynch, E. K. (2013). A turn toward avoidance? Selective exposure to online political information, 2004-2008. Political Behavior, 35(1), 113-134.

Garrett, R. K., Nisbet, E. C., \& Lynch, E. K. (2013). Undermining the corrective effects of media-based political fact checking? The role of contextual cues and naïve theory. Journal of Communication, 63, 617-637. Doi:10.1111/jcom.12038

Gastil, J., Black, L., \& Moscovitz, K. (2008). Ideology, attitude change, and deliberation in small face-to-face groups. Political Communication, 25(1), 23-46. 
Geer, J. G. (2006). In Defense of Negativity: Attack Ads in Presidential Campaigns. Chicago: University of Chicago Press.

Gerber, A. S., Huber, G. A., Doherty, D., \& Dowling, C. M. (2011). Personality traits and the consumption of political information. American Politics Research, 39(1), 32-84.

Gil de Zúñiga, H., \& Liu, J. H. (2017). Second screening politics in the social media sphere: Advancing research on dual screen use in political communication with evidence from 20 countries. Journal of Broadcasting \& Electronic Media, 61(2), 193-219.

Gil de Zuniga, H., Correa, T., \& Valenzuela, S. (2012). Selective exposure to cable news and immigration in the US: The relationship between FOX News, CNN, and attitudes toward Mexican immigrants. Journal of Broadcasting \& Electronic Media, 56(4), 597-615.

Gilardi, F., Gessler, T., Kubli, M., \& Müller, S. (2021). Social media and political agenda setting. Political Communication, 1-22.

Glynn, C. J., Huge, M., Reineke, J. B., Hardy, B. W., \& Shanahan, J. (2007). When Oprah intervenes: Political correlates of daytime talk show viewing. Journal of Broadcasting \& Electronic Media, 51(2), 228-244.

Godes, D., Mayzlin, D., Yubo, C., Das, S., Dellarocas, C., Pfeiffer, B., Libai, B., Sen, S., Shi, M., \& Verlegh, P. (2005). The firm's management of social interactions. Marketing Letters, 16, 415-428.

González-Bailón, S. (2013). Social science in the era of big data. Policy \& Internet, 5(2), $147-$ 160.

Graber, D., \& Smith, J. M. (2005). Political communication faces the $21^{\text {st }}$ century. Journal of Communication. 55. 479-507. 10.1093/joc/55.3.479.

Graham, R., \& Smith, S. (2016). The content of our\# characters: Black Twitter as counterpublic. Sociology of Race and Ethnicity, 2(4), 433-449.

Grimmer, J., \& Stewart, B. M. (2013). Text as data: The promise and pitfalls of automatic content analysis methods for political texts. Political Analysis, 21(3), 267-297.

Gross, K. (2008). Framing persuasive appeals: Episodic and thematic framing, emotional response, and policy opinion. Political Psychology, 29: 169-192.

Guess, A. M. (2021, February 9). (Almost) Everything in Moderation: New Evidence on Americans' Online Media Diets. American Journal of Political Science, February. https://doi.org/10.1111/ajps.12589 
Guess, A.M., Lyons, B., Nyhan, B., \& Reifler, J.. 2018. Avoiding the echo chamber about echo chambers: Why selective exposure to like-minded political news is less prevalent than you think." The Knight Foundation.

Guess, A. M., \& Munger, K. (2020, April 7). Digital literacy and online political behavior. Unpublished manuscript. https://doi.org/10.31219/osf.io/3ncmk

Guess, Andrew \& Nagler, Jonathan \& Tucker, Joshua. (2019). Less than you think: Prevalence and predictors of fake news dissemination on Facebook. Science Advances. 5(1): eaau4586. DOI: $10.1126 /$ sciadv.aau4586.

Gurevitch M, Coleman S, \& Blumler, J.G. (2009). Political Communication - Old and New Media Relationships. The ANNALS of the American Academy of Political and Social Science, 625(1):164-181.

Guthrie E.R. (1935). The Psychology of Learning. New York: Harper \& Row.

Guo, L., \& Vargo, C. (2020). "Fake news" and emerging online media ecosystem: An integrated intermedia agenda-Setting analysis of the 2016 US presidential election. Communication Research, 47(2), 178-200.

Halpern, D., \& Gibbs, J. (2013). Social media as a catalyst for online deliberation? Exploring the affordances of Facebook and YouTube for political expression. Computers in Human Behavior, 29(3), 1159-1168.

Hanson, G., Haridakis, P. M., Cunningham, A. W., Sharma, R., \& Ponder, J. D. (2010). The 2008 presidential campaign: Political cynicism in the age of Facebook, MySpace, and YouTube. Mass Communication and Society, 13(5), 584-607.

Hardy, B. W., Gottfried, J. A., Winneg, K. M., \& Jamieson, K. H. (2014). Stephen Colbert's civics lesson: How Colbert Super PAC taught viewers about campaign finance. Mass Communication and Society, 17(3), 329-353.

Hargittai, E. (2002). Second-level digital divide: Differences in people's online skills. First Monday, 7(4).

Hargittai, E. (2005). Survey measures of web-oriented digital literacy. Social Science Computer Review, 23(3): 371-379.

Harlow, S., \& Benbrook, A. (2019). How \#Blacklivesmatter: Exploring the role of hip-hop celebrities in constructing racial identity on Black Twitter. Information, Communication \& Society, 22(3), 352-368.

Haselmayer, M., \& Jenny, M. (2017). Sentiment analysis of political communication: combining a dictionary approach with crowdcoding. Quality \& Quantity, 51(6), 2623-2646. 
Haslam, S. A., Turner, J. C., Oakes, P. J., McGarty, C., \& Hayes, B. K. (1992). Contextdependent variation in social stereotyping 1: The effects of intergroup relations as mediated by social change and frame of reference. European Journal of Social Psychology, 22(1), 3-20.

Hasell, A. \& Weeks, B. E. (2016). Partisan provocation: the role of partisan news use and emotional responses in political information sharing in social media. Human Communication Research, 42, 641-661.

Hermida, A., Lewis, S. C., \& Zamith, R. (2014). Sourcing the Arab Spring: A case study of Andy Carvin's sources on Twitter during the Tunisian and Egyptian revolutions. Journal of Computer-Mediated Communication, 19(3), 479-499.

Ho, S. S., Scheufele, D. A., \& Corley, E. A. (2013). Factors influencing public risk-benefit considerations of nanotechnology: Assessing the effects of mass media, interpersonal communication, and elaborative processing. Public Understanding of Science, 22(5), 606-623.

Holbert, L. R., \& Geidner, N. (2009). The 2008 election: Highlighting the need to explore additional communication subfields to advance political communication. Communication Studies, 60(4), 344-358.

Horton, D., \& Richard Wohl, R. (1956). Mass communication and para-social interaction : Observations on intimacy at a distance. Psychiatry, 19(3), 215-229.

Huber, B., Gil de Zúñiga, H., Diehl, T., \& Liu, J. (2019). Effects of second screening: Building social media social capital through dual screen use. Human Communication Research, 45(3), $334-365$.

Huddy, L. (2001). From social to political identity: A critical examination of social identity theory. Political Psychology, 22(1), 127-156.

Huddy, L., Mason, L., \& Aarøe, L. (2015). Expressive partisanship: campaign involvement, political emotion, and partisan identity. American Political Science Review, 109(1), 1-17.

Hull, C.L. (1943). Principles of Behavior. New York: Appleton-Century Crofts.

Iyengar, S. (1991). Is Anyone Responsible? How Television Frames Political Issues. Chicago: University of Chicago Press.

Iyengar, S. (2017). A typology of media effects. In K. Kenski \& K. H. Jamieson (eds.), The Oxford Handbook of Political Communication (pp. 59-68). New York: Oxford University Press.

Iyengar, S., \& Kinder, D. (1987). News that Matters: Television and American Opinion. Chicago: University of Chicago Press.

Iyengar, S., Sood, G., \& Lelkes, Y. (2012). Affect, not ideology: A social identity perspective on polarization. Public Opinion Quarterly, 76(3), 405-431. 
Jacobsen, T. (2006). Bridging the arts and sciences: A framework for the psychology of aesthetics. Project Muse, 39(2), 155-162.

Jacobson, S. (2013). Does audience participation on Facebook influence the news agenda? A case study of the Rachel Maddow Show. Journal of Broadcasting \& Electronic Media, 57(3), 338-355.

Jagers, J., \& Walgrave, S. (2007). Populism as political communication style. European Journal of Political Research, 46(3), 319-345.

Jamieson, K. H. (2013, October). Messages, micro-targeting, and new media technologies. The Forum, 11(3), 429-435.

Jamieson, K. H. (2017). Creating the hybrid field of political communication: A five-decadelong evolution of the concept of effects. In K. Kenski \& K. H. Jamieson (eds.), The Oxford Handbook of Political Communication (pp. 15-46). New York: Oxford University Press.

Jamieson, K. H. (2020). Cyberwar: How Russian Hackers and Trolls Helped Elect a President: What We Don't, Can't, and Do Know. Oxford: Oxford University Press.

Jamieson, K. H. \& Albarracin, D. (2020). The relation between media consumption and misinformation at the outset of the SARS-CoV-2 pandemic in the U.S. The Harvard Kennedy School Misinformation Review, 1, 1-22. DOI: https://doi.org/10.37016/mr-2020-012

Jerit, J., Barabas, J., Pollock, W., Banducci, S., Stevens, D., \& Schoonvelde, M. (2016). Manipulated vs. measured: Using an experimental benchmark to investigate the performance of self-reported media exposure. Communication Methods and Measures, 10(2-3), 99-114.

Jones-Jang, S. M., Heo, Y. J., McKeever, R., Kim, J. H., Moscowitz, L., \& Moscowitz, D. (2020). Good news! Communication findings may be underestimated: Comparing effect sizes with self-reported and logged smartphone use data. Journal of Computer-Mediated Communication, 25(5), 346-363.

Jost, J. T., Glaser, J., Sulloway, F. J., \& Kruglanski, A. W. (2003). Political conservatism as motivated social cognition. Psychological Bulletin, 129(3), 339-375.

Jungherr, A. (2015). Analyzing Political Communication with Digital Trace Data: The Role of Twitter Messages in Social Science Research. Cham: Springer.

Jürgens, P., Stark, B., \& Magin, M. (2020). Two half-truths make a whole? On bias in selfreports and tracking data. Social Science Computer Review, 38(5), 600-615.

Kahn, K. F. \& Kenney, P. J. (1999). Do negative campaigns mobilize or suppress turnout? Clarifying the relationship between negativity and participation. American Political Science Review, 93, 877-889. 
Karpf, D., Kreiss, D., Nielsen, R. K., \& Powers, M. (2015). Qualitative Political Communication| Introduction: The role of qualitative methods in political communication Research: Past, present, and future. International Journal of Communication, 9, 19.

Katz, E., Blumler, J. G., \& Gurevitch, M. (1973). Uses and gratifications research. Public Opinion Quarterly, 37(4), 509-523.

Katz, E., \& Lazarsfeld, P. F. (1955). Personal Influence: The Part Played by People in The Flow of Mass Communication. New York: Free Press.

Kelly, D. (2019). Evaluating the news 2 Mis) perceptions of objectivity and credibility. Political Behavior, 41(2), 445-471.

Kim, Y., \& Lowrey, W. (2015). Who are citizen journalists in the social media environment? Personal and social determinants of citizen journalism activities. Digital Journalism, 3(2), 298314.

Klapper, J. T. (1960). The Effects of Mass Communications. Glencoe: Free Press.

Kleis Nielsen, R., \& Ganter, S. A. (2018). Dealing with digital intermediaries: A case study of the relations between publishers and platforms. New Media \& Society, 20(4), 1600-1617.

Klinger, U., \& Svensson, J. (2015). The emergence of network media logic in political communication: A theoretical approach. New Media \& Society, 17(8), 1241-1257.

Knobloch-Westerwick, S., \& Kleinman, S. B. (2012). Preelection selective exposure: confirmation bias versus informational utility. Communication Research, 39(2), 170-193.

Kornhauser, W. (1959). The Politics of Mass Society. New York: Free Press.

Kosmidis, S. \& Theocharis, Y. (2020). Can social media incivility induce enthusiasm? Evidence from survey experiments. Public Opinion Quarterly, 84, 284-308.

Kraft, P.W., Krupnikov, Y., Milita, K., Ryan, J. B., \& Soroka, S. (2020). Social media and the changing information environment: sentiment differences in read versus recirculated news content. Public Opinion Quarterly, 84(1), 195-215.

Kreiss, D., \& McGregor, S. C. (2018). Technology firms shape political communication: The work of Microsoft, Facebook, Twitter, and Google with campaigns during the 2016 US presidential cycle. Political Communication, 35(2), 155-177.

Krotzek, L. J. (2019). Inside the voter's mind: the effect of psychometric microtargeting on feelings toward and propensity to vote for a candidate. International Journal of Communication, 13,21 . 
Kruglanski, A. W., Molinario, E., \& Sensales, G. (2021). Why Populism Attracts: On the Allure of Certainty and Dignity. In J. P. Forgas, W. D. Crano, \& K. Fieldler (eds.), The Psychology of Populism: The Tribal Challenge to Liberal Democracy (pp. 158-173). New York: Routledge.

Kruikemeier, S., Sezgin, M., \& Boerman, S. C. (2016). Political microtargeting: Relationship between personalized advertising on Facebook and voters' responses. Cyberpsychology, Behavior, and Social Networking, 19(6), 367-372.

Kuklinski, J. H., Quirk, P. J., Jerit, J., Schwieder, D., \& Rich, R. F. (2000). Misinformation and the currency of democratic citizenship. Journal of Politics, 62(3), 790-816.

LaMarre, H. L., \& Landreville, K. D. (2009). When is fiction as good as fact? Comparing the influence of documentary and historical reenactment films on engagement, affect, issue interest, and learning. Mass Communication and Society, 12(4), 537-555.

LaMarre, H. L., Landreville, K. D., \& Beam, M. A. (2009). The irony of satire: Political ideology and the motivation to see what you want to see in The Colbert Report. The International Journal of Press/Politics, 14(2), 212-231.

Landreville, K. D., Holbert, R. L., \& LaMarre, H. L. (2010). The influence of late-night TV comedy viewing on political talk: A moderated-mediation model. The International Journal of Press/Politics, 15(4), 482-498.

Lantian, A., Muller, D., Nurra, C., \& Douglas, K. M. (2017). I know things they don't know! The role of need for uniqueness in belief in conspiracy theories. Social Psychology, 48(3): 160173.

Lasswell, H.D. (1927). Propaganda Technique in the World War. Cambridge: MIT Press.

Lasswell, H.D. (1930). Psychopathology and Politics. Chicago: University of Chicago Press.

Lasswell, H. D. (1935). World Politics and Personal Insecurity. New York: Free Press

Lasswell, H.D. (1948). The structure and function of communication in society. In L. Bryson (ed.), The Communication of Ideas. New York: Institute for Religious and Social Studies.

Lazarsfeld, P. F., Berelson, B., \& Gaudet, H. (1948). The People's Cchoice. New York: Columbia University Press.

Lee, J. K., Choi, J., Kim, C., \& Kim, Y. (2014). Social media, network heterogeneity, and opinion polarization. Journal of communication, 64(4), 702-722.

Lee, E. J., Kim, H. S., \& Cho, J. (2017). How user comments affect news processing and reality perception: Activation and refutation of regional prejudice. Communication Monographs, 84(1), 75-93. 
Lee, E. J., \& Shin, S. Y. (2012). Are they talking to me? Cognitive and affective effects of interactivity in politicians' Twitter communication. Cyberpsychology, Behavior, and Social Networking, 15(10), 515-520.

Lelkes, Y, Sood, G., \& Iyengar, S. (2017). The hostile audience: The effect of access to broadband internet on partisan affect. American Journal of Political Science, 61(1), 5-20.

Lewandowsky, S. \& van der Linden, S. (2021). Countering misinformation and fake news through inoculation and prebunking. European Review of Social Psychology, DOI:

$10.1080 / 10463283.2021 .1876983$

Lewis, S. C., Zamith, R., \& Hermida, A. (2013). Content analysis in an era of big data: A hybrid approach to computational and manual methods. Journal of Broadcasting \& Electronic Media, $57(1), 34-52$.

Long, J. A., Eveland Jr, W. P., \& Slater, M. D. (2019). Partisan media selectivity and partisan identity threat: The role of social and geographic context. Mass Communication and Society, $22(2), 145-170$.

Luo, Y. (2014). The Internet and agenda setting in China: The influence of online public opinion on media coverage and government policy. International Journal of Communication, 8, 24.

Mancini, P. (2013). Media fragmentation, party system, and democracy. The International Journal of Press/Politics, 18(1), 43-60.

Marcus, G., Neuman, W. R., \& MacKuen, M. (2000). Affective Intelligence and Political Judgment. Chicago: University of Chicago Press.

Marietta, M. \& Barker, D. C. (2019). One Nation, Two Realities: Dueling Facts in American Democracy. New York: Oxford University Press.

Masip, P., Suau-Martínez, J., \& Ruiz-Caballero, C. (2018). Questioning the selective exposure to news: understanding the impact of social networks on political news consumption. American Behavioral Scientist, 62(3), 300-319.

Mason, L. (2018). Uncivil Agreement: How Politics Became Our Identity. Chicago: University of Chicago Press.

Mast, J., Coesemans, R., \& Temmerman, M. (2017). Hybridity and the news: Blending genres and interaction patterns in new forms of journalism. Journalism, 18(1), 3-10.

Mattes, K. \& Redlawsk, D. P. (2014). The Positive Case for Negative Campaigning. Chicago: Chicago University Press.

McCombs, M. E. (2004). Setting the Agenda: The Mass Media and Public Opinion. Cambridge: Polity Press. 
McCombs, M., \& Ghanem, S. I. (2001). The convergence of agenda setting and framing. In S. Reese, O.H. Gandy, Jr., \& A. E. Grant (eds), Framing Public Life: Perspectives on Media and Our Understanding of the Social World. New York: Routledge.

McCombs, M., Llamas, J. P., Lopez-Escobar, E., \& Rey, F. (1997). Candidate images in Spanish elections: Second-level agenda-setting effects. Journalism \& Mass Communication Quarterly, 74(4), 703-717.

McCombs, M. E., \& Shaw, D. L. (1972). The agenda-setting function of mass media. Public Opinion Quarterly, 36(2), 176-187.

McCombs, M. E., \& Shaw, D. L. (1993). The evolution of agenda-setting research: Twenty-five years in the marketplace of ideas. Journal of Communication, 43, 58-67.

McGregor, S. C. (2019). Social media as public opinion: How journalists use social media to represent public opinion. Journalism, 20(8), 1070-1086.

McLeod, J. M., \& McDonald, D. G. (1985). Beyond simple exposure: Media orientations and their impact on political processes. Communication Research, 12(1), 3-33.

McNair, B. (2011). An Introduction to Political Communication. New York: Routledge.

Meraz S (2009) Is there an elite hold? Traditional media to social media agenda setting influence in blog networks. Journal of Computer-Mediated Communication, 14(3): 682-707.

Mercieca, J. (2020). Demagogue for President: The Rhetorical Genius of Donald Trump. College Station, Texas A\&M University Press.

Merton, R. K., Fiske, M., \& Curtis, A. (1946). Mass Persuasion: The Social Psychology of a War Bond Drive. New York: Harper.

Merton, R. K., \& Lazersfeld, P. F. (1950). Continuities in Social Research: Studies in the Scope and Method of "The American Soldier." New York: Free Press.

Messing, S., \& Westwood, S. J. (2014). Selective exposure in the age of social media: Endorsements trump partisan source affiliation when selecting news online. Communication Research, 41(8), 1042-1063.

Miller, J. M. \& Krosnick, J. A.. (1997). The anatomy of news media priming. In S. Iyengar \& R. Reeves (eds), Do the Media Govern? Politicians, Voters, and Reporters in America. Thousand Oaks: Sage.

Miller, J. M. (2007). Examining the mediators of agenda setting: A new experimental paradigm reveals the role of emotions." Political Psychology, 28(6): 689-717. 
Miller, J. M., \& Krosnick, J. A. (2000). News media impact on the ingredients of presidential evaluations: Politically knowledgeable citizens are guided by a trusted source. American Journal of Political Science, 44(2), 301-315.

Mills, C. W. (1951). The New Middle Class, I. In The New Middle Classes (pp. 189-202). London: Palgrave Macmillan.

Mills, C. W. (1956). The Power Elite. New York: Oxford University Press.

Moy, P., Xenos, M. A., \& Hess, V. K. (2006). Priming effects of late-night comedy. International Journal of Public Opinion Research, 18(2), 198-210.

Mudde, C. (2004). The populist zeitgeist. Government and opposition, 39(4), 541-563.

Muddiman, A. (2018). The Technical, the Personal, and the Political: Understanding Journalists and News Users' Engagement in The New York Times Comments Section. In Digital Discussions (pp. 111-133). New York: Routledge.

Muddiman, A., Stroud, N. J., \& McCombs, M. (2014). Media fragmentation, attribute agenda setting, and political opinions about Iraq. Journal of Broadcasting \& Electronic Media, 58(2), 215-233.

Munger, K. (2020). All the news that's fit to click: The economics of clickbait media. Political Communication, 37(3), 376-397.

Munger, K., Gopal, I., Nagler, J., \& Tucker, J. A. (2021). Accessibility and Generalizability: Are Social Media Effects Moderated by Age or Digital Literacy? Research and Politics, April-June, $1-16$.

Munger K, \& Phillips J. (2020). Right-wing YouTube: A supply and demand perspective. The International Journal of Press/Politics, 1-45. doi:10.1177/1940161220964767

Mutz, D. C. \& Reeves, B. (2005). The new videomalaise: effects of televised incivility on political trust. American Political Science Review, 99, 1-15.

Nai, A., \& Martinez I Coma, F. (2019). The personality of populists: Provocateurs, charismatic leaders, or drunken dinner guests? West European Politics, 42(7), 1337-1367.Chicago

Nee, R. C., \& Barker, V. (2020). Co-viewing Virtually: Social Outcomes of Second Screening with Televised and Streamed Content. Television \& New Media, 21(7), 712-729.

Negroponte, N. (1995). Being Digital. New York: Knopf

Nelson, J. L., \& Webster, J. G. (2017). The myth of partisan selective exposure: A portrait of the online political news audience. Social Media+Society, 3(3), DOI: 2056305117729314. 
Nelson, T. E. \& Oxley, Z. M.. (1999). Issue framing effects on belief importance and opinion. Journal of Politics, 61(4), 1040-1067.

Nelson, T. E., Oxley, Z. M., \& Clawson, R. A. (1997). Toward a psychology of framing effects. Political Behavior, 19(3), 221-246

Neuman, R. W., Guggenheim, L., Mo Jang, S., \& Bae, S. Y. (2014). The dynamics of public attention: Agenda-setting theory meets big data. Journal of Communication, 64(2), 193-214.

Neuman, R. W., Marcus, G. E., MacKuen, M, \& Crigler, A., (eds.). (2007). The Affect Effect: Dynamics of Emotion in Political Thinking and Behavior. Chicago: Chicago University Press.

Nielsen, R. K., \& Vaccari, C. (2013). Do people "like" politicians on Facebook? Not really. Large-scale direct candidate-to-voter online communication as an outlier phenomenon. International Journal of Communication, 7, 24.

Nielsen, R. K. (2016). News media, search engines and social networking sites as varieties of online gatekeepers. In Broersma, M., \& Peters, C. (eds.), Rethinking Journalism Again: Societal Role and Public Relevance in a Digital Age (pp. 93-108). New York: Routledge.

Niven, D., Lichter, S. R., \& Amundson, D. (2003). The political content of late night comedy. Harvard International Journal of Press/Politics, 8(3), 118-133.

Nyhan, B., Porter, E., Reifler, J. Wood, T. J. (2020). Taking fact-checks literally but not seriously? The effects of journalistic fact-checking on factual beliefs and candidate favorability. Political Behavior, 42, 939-960.

Oliver, J. E., \& Wood, T. J. (2018). Enchanted America: How Intuition and Reason Divide Our Politics. Chicago: University of Chicago Press.

Oliver, M. B. (2002). Individual differences in media effects. Media Effects: Advances in Theory and Research, 2, 507-524.

Ophir, Y., Romer, D., Jamieson, P. E., \& Jamieson, K. H. (2020). Countering misleading protobacco YouTube videos: The effects of text-based and narrative correction interventions and the role of identification. International Journal of Communication, 14, 4973-4988.

'Reilly, T. (2009). What is web 2.0? 'Reilly Media, Inc.

Ottovordemgentschenfelde, S. (2017). 'Organizational, professional, personal': An exploratory study of political journalists and their hybrid brand on Twitter. Journalism, 18(1), 64-80.

Pai, P., \& Arnott, D. C. (2013). User adoption of social networking sites: Eliciting uses and gratifications through a means-end approach. Computers in Human Behavior, 29(3), 1039-1053. 
Pal, J. (2017). Studying political communication on Twitter: the case for small data. Current Opinion in Behavioral Sciences, 18, 97-102.

Pang, H. (2018). Is mobile app a new political discussion platform? An empirical study of the effect of WeChat use on college students' political discussion and political efficacy. pLoS One, 13(8), e0202244.

Paravati, E., Naidu, E., Gabriel, S., \& Wiedemann, C. (2020). More than just a tweet: The unconscious impact of forming parasocial relationships through social media. Psychology of Consciousness: Theory, Research, and Practice, 7(4), 388.

Pariser, E. (2011). Filter Bubble: What the Internet is Hiding from You. NewYork: Penguin Press.

Parry, D. A., Davidson, B. I., Sewall, C. J., Fisher, J. T., Mieczkowski, H., \& Quintana, D. S. (2021). A systematic review and meta-analysis of discrepancies between logged and selfreported digital media use. Nature Human Behaviour, 1-13.

Parry, M. M., Moule Jr, R. K., \& Dario, L. M. (2019). Technology-mediated exposure to policecitizen encounters: A quasi-experimental assessment of consequences for citizen perceptions. Justice Quarterly, 36(3), 412-436.

Patterson, T. E. (1993). Out of Order. New York: Knopf.

Pels, D. (2003). Aesthetic representation and political style. Media and the Restyling of Politics, 41-67.

Penney, J. (2020). 'It's so hard not to be funny in this situation': Memes and humor in us youth online political expression. Television \& New Media, 21(8), 791-806.

Pennington, N., \& Winfrey, K. L. (2021). Engaging in political talk on Facebook: Investigating the role of interpersonal goals and cognitive engagement. Communication Studies, 72(1), 100114.

Pennycook, G. et al. (2021) Shifting attention to accuracy can reduce misinformation online. Nature DOI: 10.31234/OSF.IO/3N9U8

Perloff, R. M. (2015). Mass communication research at the crossroads: Definitional issues and theoretical directions for mass and political communication scholarship in an age of online media. Mass Communication and Society, 18(5), 531-556.

Perloff, R. M. (2020). The Dynamics of Persuasion: Communication and Attitudes in the Twenty-First Century. New York: Routledge. 
Petersen, M. B., Osmundsen, M., \& Bor, A. (2020). Beyond populism: The psychology of statusseeking and extreme political discontent. PsyArXiv. July 8. doi:10.31234/osf.io/puqzs.

Phillips, W. \& Milner, R. M. (2021). You Are Here: A Field Guide for Navigating Polarized Speech, Conspiracy Theories, and our Polluted Media Landscape. Cambridge: MIT Press.

Pooley, J. (2006). Fifteen pages that shook the field: Personal Influence, Edward Shils, and the remembered history of mass communication research. The ANNALS of the American Academy of Political and Social Science, 608(1), 130-156.

Prior, M. (2007). Post-Broadcast Democracy: How Media Choice Increases Inequality in Political Involvement and Polarizes Elections. New York: Cambridge University Press.

Prior, M. (2009a). Improving media effects research through better measurement of news exposure. The Journal of Politics, 71(3), 893-908.

Prior, M. (2009b). The immensely inflated news audience: Assessing bias in self-reported news exposure. Public Opinion Quarterly, 73(1), 130-143.

Prior, M. (2013). Media and political polarization. Annual Review of Political Science, 16, 101127.

Rawlings, D., Barrantes i Vidal, N., \& Furnham, A. (2000). Personality and aesthetic preference in Spain and England: Two studies relating sensation seeking and openness to experience to liking for paintings and music. European Journal of Personality, 14(6), 553-576.

Reardon, K. K., \& Rogers, E. M. (1988). Interpersonal versus mass media communication a false dichotomy. Human Communication Research, 15(2), 284-303.

Ritzer, G., \& Jurgenson, N. (2010). Production, consumption, prosumption: The nature of capitalism in the age of the digital 'prosumer'. Journal of Consumer Culture, 10(1), 13-36.

Robinson, P. (2019). Expanding the field of political communication: Making the case for a fresh perspective through "propaganda studies." Frontiers in Communication, 4(Article 26), 1-13.

Roskos-Ewoldsen, D. R., Roskos-Ewoldsen, B., \& Carpentier, F. R. D. (2002). Media priming: A synthesis. Media effects: Advances in theory and research, 2, 97-120.

Rosen, J. (2008). The people formerly known as the audience. In N. Carpentier \& B. DeCleen (eds.), Participation and Media Production: Critical Reflections on Content Creation, Cambridge: Cambridge Scientific Publishers Ltd.

Rosenblum, N. L., \& Muirhead, R. (2020). A Lot of People are Saying: The New Conspiracism and the Assault on Democracy. Princeton: Princeton University Press. 
Roth, F. S., Weinmann, C., Schneider, F. M., Hopp, F. R., \& Vorderer, P. (2014). Seriously entertained: Antecedents and consequences of hedonic and eudaimonic entertainment experiences with political talk shows on TV. Mass Communication and Society, 17(3), 379-399.

Rubin, A. M. (1983). Television uses and gratifications: The interactions of viewing patterns and motivations. Journal of Broadcasting \& Electronic Media, 27(1), 37-51.

Scacco, J. M., \& Coe, K. (2021). The Ubiquitous Presidency: Presidential Communication and Digital Democracy in Tumultuous Times. New York: Oxford University Press.

Scharkow, M. (2019). The reliability and temporal stability of self-reported media exposure: A meta-analysis. Communication Methods and Measures, 13(3), 198-211.

Scheufele, D. A. (1993). Framing as a theory of media effects. Journal of Communication, 49(1), 103-122.

Scheufele, D. A., \& Tewksbury, D. (2007). Framing, agenda setting, and priming: The evolution of three media effects models. Journal of Communication, 57(1), 9-20.

Schramm, W. (1971). The nature of communication between humans. In W. Schramm \& D.F. Roberts (eds.), The Process and Effects of Mass Communication (pp. 3-53). Urbana: University of Illinois Press.

Schramm, W., \& Carter, R. F. (1959). Effectiveness of a Political Telethon. Public Opinion Quarterly, 23(1), 121-127.

Sears, D. O., \& Freedman, J. L. (1967). Selective exposure to information: A critical review. Public Opinion Quarterly, 31(2) 194-213.

Semetko, H. A., Brzinski, J. B., Weaver, D., \& Willnat, L. (1992). TV news and US public opinion about foreign countries: The impact of exposure and attention. International Journal of Public Opinion Research, 4(1), 18-36.

Settle, J. E. (2018). Frenemies: How Social Media Polarizes America. Cambridge: Cambridge University Press.

Shah, D. V., McLeod, D. M., Rojas, H., Cho, J., Wagner, M. W., \& Friedland, L. A. (2017). Revising the communication mediation model for a new political communication ecology. Human Communication Research, 43(4), 491-504.

Shearer, E. (2021). More than eight-in-ten Americans get news from digital devices. Pew Research Center, 12.

Shehata A, \& Strömbäck J. (2013). Not (yet) a new era of minimal effects: A study of agenda setting at the aggregate and individual levels. The International Journal of Press/Politics, $18(2): 234-255$. 
Sherry, J. L. (2001). Toward an etiology of media use motivations: The role of temperament in media use. Communication Monographs, 68(3), 274-288.

Shin, J., Jian, L., Driscoll, K., \& Bar, F. (2018). The diffusion of misinformation on social media: Temporal pattern, message, and source. Computers in Human Behavior, 83, 278-287.

Shoemaker, P.J., Eichholz, M., Kim, E., \& Wrigley, B. (2001). Individual and routine forces in gatekeeping. Journalism \& Mass Communication Quarterly, 78(2):233-246.

Simas, E. N., Clifford, S., \& Kirkland, J. H. (2020). How empathic concern fuels political polarization. American Political Science Review, 114(1), 258-269.

Slater, M. D. (2007). Reinforcing spirals: The mutual influence of media selectivity and media effects and their impact on individual behavior and social identity. Communication Theory, 17(3), 281-303.

Slater, M. D. (2015). Reinforcing spirals model: Conceptualizing the relationship between media content exposure and the development and maintenance of attitudes. Media Psychology, 18(3), 370-395.

Smith, E. G., \& Neijens, P. C. (2011). The march to reliable metrics. A half-century of coming closer to the truth. Journal of Advertising Research, 51(supplement), 124-135. doi:10.2501/JAR51-1-124-135

Song, H., \& Boomgaarden, H. G. (2017). Dynamic spirals put to test: An agent-based model of reinforcing spirals between selective exposure, interpersonal networks, and attitude polarization. Journal of Communication, 67(2), 256-281.

Soroka, S. Daku, M., Hiaeshutter-Rice, D., Guggenheim, L., \& Pasek, J. (2018). Negativity and positivity biases in economic news coverage: traditional versus social media. Communication Research, 45, 1078-1098.

Spencer, D. R., \& Spencer, J. (2007). The Yellow Journalism: The Press and America's Emergence as a World Power. Evanston: Northwestern University Press.

Stepp, K. K., \& Castle, J. J. (2021). Research note: Authoritarianism, racial resentment, and attitudes on the Colin Kaepernick protests. The Social Science Journal, 1-11.

Stier, S., Breuer, J., Siegers, P., \& Thorson, K. (2020). Integrating survey data and digital trace data: Key issues in developing an emerging field. Social Science Computer Review, 38(5):503516.

Stier, S., Kirkizh, N., Froio, C., \& Schroeder, R. (2020). Populist attitudes and selective exposure to online news: A cross-country analysis combining web tracking and surveys. The International Journal of Press/Politics, 25(3), 426-446. 
Stromer-Galley, J. (2003). Diversity of political conversation on the Internet: User' perspectives. Journal of Computer-Mediated Communication, 8(3), article 6. doi: 10.1111/j.1083-

6101.2003.tb00215.x

Stroud, N. J. (2011). Niche News: The Politics of News Choice. Oxford: Oxford University Press on Demand.

Stroud, N. J. (2010). Polarization and partisan selective exposure. Journal of communication, $60(3), 556-576$.

Stroud, N. J., \& McGregor, S. (eds) (2018). Digital Discussions: How Big Data Informs Political Communication. New York: Routledge.

Su, Y., \& Hu, J. (2020). A territorial dispute or an agenda war? A cross-national investigation of the network agenda-setting (NAS) model. Journal of Information Technology \& Politics, 17(4), 357-375.

Su, Y., \& Borah, P. (2019). Who is the agenda setter? Examining the intermedia agenda-setting effect between Twitter and newspapers. Journal of Information Technology \& Politics, 16(3), 236-249.

Sundar, S. S. (2008). The MAIN model: A heuristic approach to understanding technology effects on credibility. In M. J. Metzger \& A. J. Flanagin, The John D. and Catherine T. MacArthur Foundation Series on Digital Media and Learning (pp. 73-100). Cambridge: MIT Press.

Sundar, S. S., \& Limperos, A. M. (2013). Uses and grats 2.0: New gratifications for new media. Journal of Broadcasting \& Electronic Media, 57(4), 504-525.

Sunstein, C. (2001). Republic.com. Princeton: Princeton University Press.

Sydnor, E. (2019). Disrespectful Democracy: The Psychology of Political Incivility. New York: Columbia University Press.

Tajfel, H., \& Turner, J. C. (1979). An integrative theory of inter-group conflict. In W. G. Austin \& S. Worchel (Eds.), The Social Psychology of Inter-Group Relations (pp. 33-47). Monterey: CA: Brooks/Cole.

Tandoc Jr, E. C. (2019). Tell me who your sources are: Perceptions of news credibility on social media. Journalism Practice, 13(2), 178-190.

Tedesco, J. C. (2002). Televised political advertising effects: Evaluating responses during the 2000 Robb-Allen Senatorial election. Journal of Advertising, 31(1), 37-48.

Thorndike, E. L. (1898). Animal intelligence: An experimental study of the associative processes in animals. Psychological Review Monograph Supplements, 2(4, Whole number 8). 
Thorson, K., Cotter, K., Medeiros, M., \& Pak, C. (2019). Algorithmic inference, political interest, and exposure to news and politics on Facebook. Information, Communication \& Society, 24(2), 183-200.

Thorson, K., \& Wells, C. (2016). Curated flows: A framework for mapping media exposure in the digital age. Communication Theory, 26(3), 309-328.

Thurman, N. (2008). Forums for citizen journalists? Adoption of user generated content initiatives by online news media. New Media \& Society, 10(1), 139-157.

Toff, B. \& Kalogeropoulos, A. (2020). All the news that's fit to ignore: how the information environment does and does not shape news avoidance. Public Opinion Quarterly, 84, 366-390

Törnberg, P. (2018). Echo chambers and viral misinformation: Modeling fake news as complex contagion. PloS One, 13(9), e0203958.

Towler, C. C., Crawford, N. N., \& Bennett, R. A. (2020). Shut up and play: Black athletes, protest politics, and black political action. Perspectives on Politics, 18(1), 111-127.

Towner, T. L. \& Baumgartner, J. (2021). The Internet and the 2020 Campaign. Lanham, Lexington Books.

Tran, H. (2013). Online agenda setting: A new frontier for theory development. In T. J. Johnson (ed), Agenda Setting in a 2.0 World: New Agendas in Communication. New York: Routledge.

Trujilo, K. L. \& Motta, M. (2021). How internet access drives global vaccine skepticism. International Journal of Public Opinion Research, DOI: https://doi.org/10.1093/ijpor/edab012.

Trujilo, K. L., Motta, M., Callaghan, T., \& Sylvester, S. (2021). Correcting misperceptions about the MMR vaccine: using psychological risk factors to inform targeted communication strategies. Political Research Quarterly,74(2):464-478.

Tucker, J. A., Guess, A., Barberá, P., Vaccari, C., Siegel, A., Sanovich, S., Stukal, D., \& Nyhan, B. (2018). Social media, political polarization, and political disinformation: A review of the scientific literature. Unpublished manuscript prepared for the William + Flora Hewlett Foundation, March 19, 2018. https://hewlett.org/wp-content/uploads/2018/03/Social-MediaPolitical-Polarization-and-Political-Disinformation-Literature-Review.pdf

Tufekci, Z. (2014). Engineering the public: Big data, surveillance and computational politics. First Monday, 19(7), https://doi.org/10.5210/fm.v19i7.4901.

Turner, J. C., \& Oakes, P. J. (1986). The significance of the social identity concept for social psychology with reference to individualism, interactionism and social influence. British Journal of Social Psychology, 25(3), 237-252. 
Turow, J. (1997). Breaking up America: Advertisers and the New Media World. Chicago: University of Chicago Press.

Vaccari, C., Chadwick, A., \& O'Loughlin, B. (2015). Dual screening the political: Media events, social media, and citizen engagement. Journal of Communication, 65(6), 1041-1061.

Vaidhyanathan, S. (2018). Antisocial media: How Facebook Disconnects Us and Undermines Democracy. New York: Oxford University Press.

Valentino, N. A., Banks, A. J., Hutchings, V. L., \& Davis, A. K. (2009). Selective exposure in the Internet age: The interaction between anxiety and information utility. Political Psychology, 30(4), 591-613.

Valentino, N. A., Brader, T., Groenendyk, E., Gregorowicz, K., \& Hutchings, V. L. (2011). Election night's alright for fighting: The role of emotions in political participation. Journal of Politics, 73, 156-170.

Valentino, N. A. \& Nardis, Y. (2013). The psychology of political communication: Form and consequence of the information environment. In L. Huddy, D. O. Sears, and J. S. Levy (eds), The Oxford Handbook of Political Psychology, Oxford: Oxford University Press.

Van Aelst, P., Strömbäck, J., Aalberg, T., Esser, F., De Vreese, C., Matthes, J., Hopmann, D., Salgado, S., Hubé, N., Stępińska, A., Papathanassopoulos, S., Berganza, R., Legnante, G., Reinemann, C., Sheafer, T., \& Stanyer, J. (2017). Political communication in a high-choice media environment: a challenge for democracy? Annals of the International Communication Association, 41(1), 3-27.

Van Cauwenberge, A., Schaap, G., \& Van Roy, R. (2014). TV no longer commands our full attention: Effects of second-screen viewing and task relevance on cognitive load and learning from news. Computers in Human Behavior, 38, 100-109.

Van Dijck, J. (2013). The Culture of Connectivity: A Critical History of Social Media. New York: Oxford University Press.

Vargo, C. J., \& Guo, L. (2017). Networks, big data, and intermedia agenda setting: An analysis of traditional, partisan, and emerging online US news. Journalism \& Mass Communication Quarterly, 94(4), 1031-1055.

Vargo, C. J., Guo, L., \& Amazeen, M. A. (2018). The agenda-setting power of fake news: A big data analysis of the online media landscape from 2014 to 2016. New Media \& Society, 20(5), 2028-2049.

Vijay, D., \& Gekker, A. (2021). Playing politics: How Sabarimala played out on TikTok. American Behavioral Scientist, 65(5), 712-734. 
Vosoughi, S., Roy, D., and Aral, S. (2018). The spread of true and false news online. Science, 359, 1146-1151.

Vraga, E. K. \& Bode, L. (2020). Defining misinformation and understanding its bounded nature: using expertise and evidence for describing misinformation. Political Communication, 37(1), 136-144.

Wall, M. (2015). Citizen journalism: A retrospective on what we know, an agenda for what we don't. Digital Journalism, 3(6), 797-813.

Wallace, J. (2018). Modelling contemporary gatekeeping: The rise of individuals, algorithms and platforms in digital news dissemination. Digital Journalism, 6(3), 274-293.

Walther, J. B. (2017). The merger of mass and interpersonal communication via new media: Integrating metaconstructs. Human Communication Research, 43(4), 559-572.

Walter, N., Cohen, J., Holbert, R. L., \& Morag, Y. (2020). Fact-checking: A meta-analysis of what works and for whom. Political Communication, 37(3), 350-375.

Wardle, C., \& Derakhshan, H. (2018). Thinking about 'information disorder': formats of misinformation, disinformation, and mal-information. In C. Ireton \& J. Posetti (eds), Journalism, Fake News \& Disinformation: Handbook for Journalism Education And Training (pp. 43-54).

Paris: Unesco.

Watts, D. J. (2011). Everything is Obvious:* Once You Know the Answer. New York: Crown Business.

Webster, S. (2020). American Rage: How Anger Shapes Our Politics. New York: Cambridge University Press.

Wells, C., \& Thorson, K. (2017). Combining big data and survey techniques to model effects of political content flows in Facebook. Social Science Computer Review, 35(1), 33-52.

Whiteman, D. (2004). Out of the theaters and into the streets: A coalition model of the political impact of documentary film and video. Political Communication, , 21(1), 51-69.

Wiersema, D. V., Van Der Schalk, J., \& van Kleef, G. A. (2012). Who's afraid of red, yellow, and blue? Need for cognitive closure predicts aesthetic preferences. Psychology of Aesthetics, Creativity, and the Arts, 6(2), 168.

Williams, B. A., \& Carpini, M. X. D. (2011). After Broadcast News: Media Regimes, Democracy, and the New Information Environment. Cambridge: Cambridge University Press.

Wilson, D. C., \& Brewer, P. R. (2013). The foundations of public opinion on voter ID laws: Political predispositions, racial resentment, and information effects. Public Opinion Quarterly, 77(4), 962-984. 
Winter, S. (2020). Do anticipated Facebook discussions diminish the importance of argument quality? An experimental investigation of attitude formation in social media. Media Psychology, 23(1), 79-106.

Winter, S., Brückner, C., \& Krämer, N. C. (2015). They came, they liked, they commented: Social influence on Facebook news channels. Cyberpsychology, Behavior, and Social Networking, 18(8), 431-436.

Wojcieszak, M. E., \& Mutz, D. C. (2009). Online groups and political discourse: Do online discussion spaces facilitate exposure to political disagreement? Journal of Communication, 59(1), 40-56.

Wollebæk, D., Karlsen, R., Steen-Johnsen, K., \& Enjolras, B. (2019). Anger, fear, and echo chambers: The emotional basis for online behavior. Social Media+Society, 5(2), 2056305119829859.

Xenos, M. A., \& Becker, A. B. (2009). Moments of Zen: Effects of The Daily Show on information seeking and political learning. Political Communication, 26(3), 317-332.

Xiong, Y., Cho, M., \& Boatwright, B. (2019). Hashtag activism and message frames among social movement organizations: Semantic network analysis and thematic analysis of Twitter during the\# MeToo movement. Public Relations Review, 45(1), 10-23.

Yang, G. (2016). Narrative agency in hashtag activism: The case of\# BlackLivesMatter. Media and Communication, 4(4), 13.

Yarchi, M., Baden, C., \& Kligler-Vilenchik, N. (2020). Political polarization on the digital sphere: A cross-platform, over-time analysis of interactional, positional, and affective polarization on social media. Political Communication, 1-42.

Yoo, S. W., Kim, J. W., \& Gil de Zúñiga, H. (2017). Cognitive benefits for senders: Antecedents and effects of political expression on social media. Journalism \& Mass Communication Quarterly, 94(1), 17-37.

Young, D. G. (2004). Late-night comedy in election 2000: Its influence on candidate trait ratings and the moderating effects of political knowledge and partisanship. Journal of Broadcasting \& Electronic Media, 48(1), 1-22.

Young, D. G. (2008). The privileged role of the late-night joke: Exploring humor's role in disrupting argument scrutiny. Media Psychology, 11(1), 119-142.

Young, D. G. (2019). Irony And Outrage: The Polarized Landscape of Rage, Fear, and Laughter in the United States. New York: Oxford University Press. 
Young, D. G., Bagozzi, B. E., Goldring, A., Poulsen, S., \& Drouin, E. (2019). Psychology, political ideology, and humor appreciation: Why is satire so liberal? Psychology of Popular Media Culture, 8(2), 134.

Young, D. G., \& Gray, J. (2013). Breaking boundaries: Working across the methodological and epistemological divide in the study of political entertainment. International Journal of Communication, 7, 4.

Young, D. G., Jamieson, K. H., Poulsen, S., \& Goldring, A. (2018). Fact-checking effectiveness as a function of format and tone: Evaluating Factcheck.org and Flackcheck.org. Journalism \& Mass Communication Quarterly, 95(1), 49-75.

Young, D. G., \& McGregor, S. (2020). Mass propaganda used to be difficult, but Facebook made it easy. The Washington Post.

Young, L., \& Soroka, S. (2012). Affective news: The automated coding of sentiment in political texts. Political Communication, 29(2), 205-231.

Zamith, R., \& Lewis, S. C. (2015). Content analysis and the algorithmic coder: What computational social science means for traditional modes of media analysis. The ANNALS of the American Academy of Political and Social Science, 659(1), 307-318.

Zarouali, B., Dobber, T., De Pauw, G., \& de Vreese, C. (2020). Using a personality-profiling algorithm to investigate political microtargeting: Assessing the persuasion effects of personalitytailored ads on social media. Communication Research, doi: 10.1177/0093650220961965.

Zhang, Y., Wang, Y., Foley, J., Suk, J., \& Conathan, D. (2017, July). Tweeting mass shootings: the dynamics of issue attention on social media. In Proceedings of the 8th International Conference on Social Media \& Society (pp. 1-5).

Zuckerman, A.S., ed. 2005. The Social Logic of Politics: Personal Networks as Contexts for Political Behavior. Philadelphia: Temple University Press.

Zuiderveen Borgesius, F., Trilling, D., Möller, J., Bodó, B., De Vreese, C. H., \& Helberger, N. (2016). Should we worry about filter bubbles? Internet Policy Review, 5(1), 1-16. 